\title{
Savannah River Site Management Response Plan for Chemical Safety Vulnerability Field Assessment (U)
}

by

S. R. Salaymeh

Westinghouse Savannah River Company

Savannah River Site

Aiken, South Carolina 29808

E. J. Kahal

S. L Murphy

DOE Contract No. DE-AC09-89SR18035

This paper was prepared in connection with work done under the above contract number with the U. S.

Department of Energy. By acceptance of this paper, the publisher and/or recipient acknowledges the U.S. Government's right to retain a nonexclusive, royalty-free license in and to any copyright covering this paper, along with the right to reproduce and to authorize others to reproduce all or part of the copyrighted paper. 


\section{DISCLAMMIR}

Portions of this document may be illegible in electronic image products. Images are produced from the best available original document. 
HSRC-RP-94-863

Rev. 1

Savannah River Site Management Response plan for

Chemical safety vulnerability field Assessment (U)

B. J. Kahal

S. I. Kurphy

S. R. Salaymeh

September, 1994

Westinghouse Savannah River Company

Savannah River Site

Alken, SC 29803

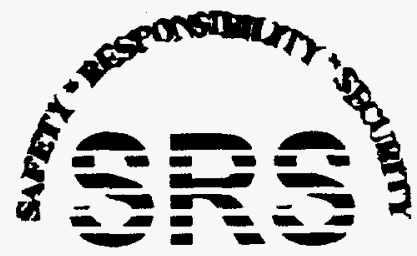

SAVANNAH RIVER SITE PREPARED FOR THE U.S. DEPARTMENT OF ENERGY UNDER CONTRACT NO. DE-ACO9-89SR18035

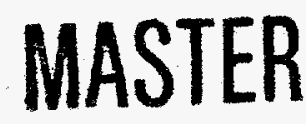

DCTUDISON OF THE DOCWET IS UMLMTED

DE DC.

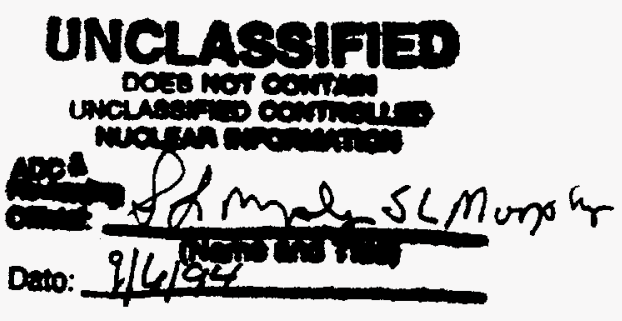


Acknowledgment

The authors would like to acknowledge the contributions of $D$. $W$. Harrison, J. C. Hudson, D. A. Jackson, R. W. Reynolds, R. A. Scaggs, C. F. Shuler and G. H. Street in the development of this report.

\section{DISCLAIMER}

This report was prepared as an account of work sponsored by an agency of the United States Government. Neither the United States Government no: any agency thereof, nor any of their employees, makes any warranty, express or implied, or assumes any legal liability or responsibility for the accuracy, completeness, or usefulness of any information, apparatus, product, or process disclosed, or represents that its use would not infringe privately owned rights. Reference herein to any specific commercial product, process, or service by trade name, trademark, manufacturer, or otherwise does not necessarily constitute or imply its endorsement, recommendation, or favoring by the United States Government or any agency thereof. The views and opinions of authors expressed herein do not necessarily state or reflect those of the United States Government or any agency thereof.

This report has been reproduced directly from the best available copy.

Available to DOE and DOE contractors from the Office of Scientific and Technical Information, P.O. Box 62, Oak Ridge, TN 37831; prices available from (615) 576-8401.

Available to the public from the National Technical Information Service, U.S. Department of Commerce; 5285 Port Royal Road, Springfield, VA 22161. 
TSRC-RP $-94-863$

REV. 1

Keyworda:

Process Safety, Process Hazard Reviews Chemicals, Chemical stores

Retention: Lifetime

Savannah River site Management Response plan for Chemical safety Vulnerability field Assessment (U)

B. J. Rahal

s. I. Murphy

S. R. Salaymeh

September 1994

Westinghouse Savannah Rlver Company Savannah River Site Alken, SC 29803

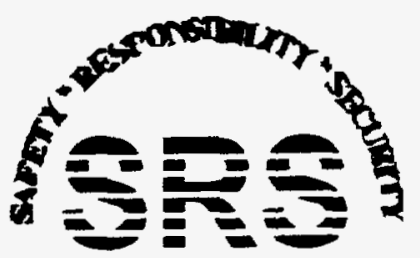

SAVANNAH RIVER SITE PREPARED FOR THE U.S. DEPARTMENT OF ENERGY UNDER CONTRACT NO. DE-AC09-89SR18035 
CONTENTS

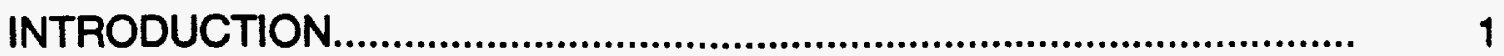

RESPONSE SUMMARY................................................................

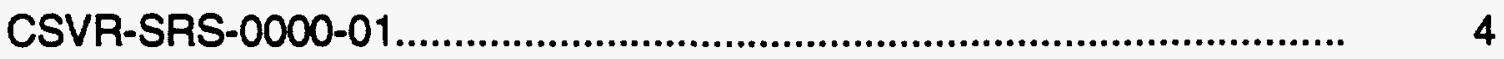

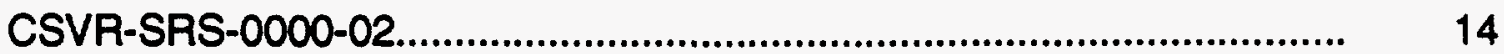

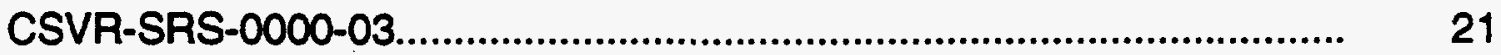

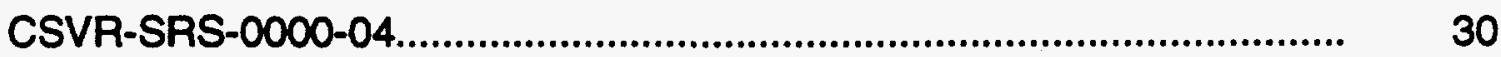

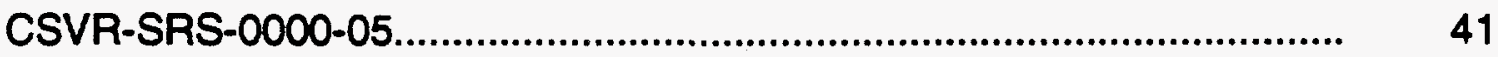

LIST OF FIGURES

1. SRS Site-Wide Chemical Safety Program

Organizational Structure \& Responsibilities................................. 3 


\section{Savannah Rlver Site \\ Management Response Plan \\ for \\ Chemical Safety Vulnerability Field Assessment}

\section{Introduction}

As part of the U. S. Department of Energy's (DOE) initiative to identify potential chemical safety vulnerabilities in the DOE complex, the Chemical Safety Vulnerability Core Working Group issued a field verification assessment report. While the report concluded that Savannah River Site (SRS) is moving in a positive direction, the report also identified five chemical safety vulnerabilities with broad programmatic impact that are not easily nor quickly remedied. The May 1994 SRS Management Response Plan addressed the five SRS vulnerabilities identified in the field assessment report. The SRS response plan listed observations supporting the vulnerabilities and any actions taken or planned toward resolution. Many of the observations were resolved by simple explanations, such as the existence of implementation plans for Safety Analysis Report updates. Recognizing that correcting individual observations does not suffice in remedying the vulnerabilities, a task team was assembled to address the broader programmatic issues and to recommend corrective actions.

\section{Response Summary}

This September 1994 SRS Management Response Plan outlines the corrective actions SRS will take to provide a coordinated chemical safety program. The foundation for a sitewide coordinated chemical safety program is based on using the existing safety infrastructure ensured by the Site Safety Review Committee (SSRC). The SSRC has assumed responsibility for ensuring that a coordinated site chemical safety program will be implemented through the existing Process Safety Management (PSM) subcommittee and the newly formed Chemical Commodity Management Center (CCMC) per Figure 1. The PSM Subcommittee will establish a sitewide PSM program consistent with the DOE requirements and site policy. The CCMC will be responsible for the acquisition of new chemicals/chemical products and will work with chemical and environmental coordinators to manage the disposition of excess chemicals and to maintain a site chemical inventory.

In response to the observation that hazards analysis/reviews of DOE related projects were inadequate, WSRC is applying an overall, programmatic approach rather than several superficial fixes. First, an Industrial Hygiene Screening Checklist is being developed to provide a uniform approach to the review of work packages. Second, an industrial hygienist has been assigned to review transition, decontamination and decommissioning (D\&D) and environmental restoration projects. In addition, two procedures in the Site Safety Manual are being revised to require a graded approach hazards review appropriate to the scope of the job and applicable to activities requiring a Works Clearance Permit and Process System Access. A Basic Requirements document, "SRS Requirements Applicability Evaluation Program for Decommissioning", was issued in June 1994. This document outlines the 
requirements and the sequence of activities required to transition a facility from deactivation to safe storage and eventual D\&D.

The last part of the coordinated chemical safety program is the chemical inventory management and enhanced sitewide hazard communication. The mission of the CCMC will include the acquisition of all chemicals and chemical products, the disposition of unused or excess chemicals, and a database support for site groups required to report chemical data and waste minimization initiatives to external agencies. This will include the maintenance of a sitewide chemical inventory and a means of tracking chemicals from procurement, to ultimate use, to excessing. As a part of the writing/reviewing/approving process for the procurement of chemicals, criteria will include evaluating non-hazardous substitutes and re-using current excess and existing inventories. Current stock items will be reviewed for opportunities to reduce inventory and toxicity levels.

Because of the timing of this response plan, Action Items committed for FY95 are not included in the FY 95 Annual Operating Plan. A change control notice may be required in order to shift priorities and provide funding for these activities. 


\section{SRS Sitewide Chemical Safety Program}

Organizational Structure \& Responsibilities

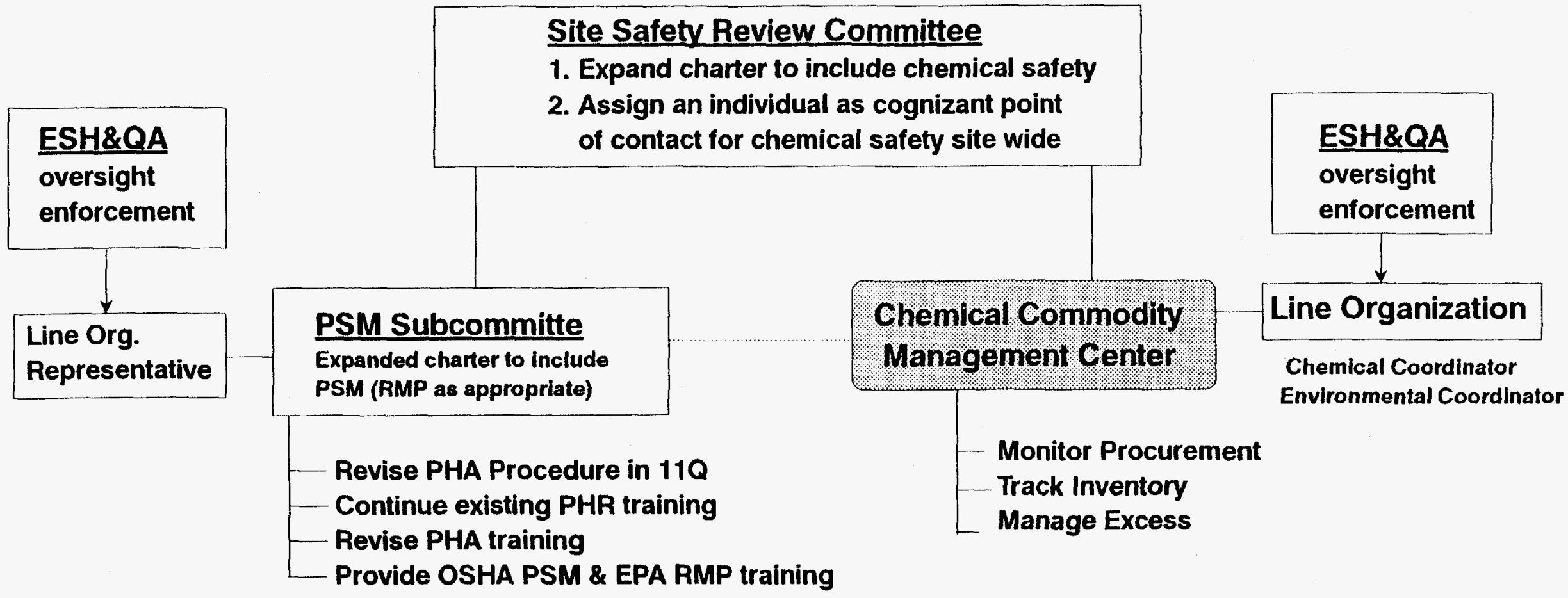

Figure 1 - SRS Sitewide Chemical Safety Program 


\section{CHEMICAL SAFETY VULNERABILITY REVIEW}

Point of Contact: E. J. Kahal / S. R. Salaymeh

\section{Vulnerability}

Some facility work packages are not receiving adequate hazards analysis.

\section{Summan of Vulnerability}

In some cases, the chemical safety and hazard analyses for work planning and emergency response planning are not complete or adequate. This problem is compounded for Decontamination and Decommissioning (D\&D) activities due to inexperience in conducting these types of activities, lack of overall understanding of the associated problems, and lack of defined operating parameters. Also, chemical safety has not been given sufficlent priority in the past.

\section{Response}

WSRC continually strives to improve safety documentation and has submitted a detailed implementation plan for DOE Order 5480.23. Basis for Interim Operations (BIO) documents are being developed on an accelerated basis and will satisfy the need for chemical safety analysis. A thorough characterization and hazards analysis will be required before any D\&D activity will be performed by the WSRC Solid Waste/Environmental Restoration and Transition D\&D Department. A Basic Requirement document, "SRS Requirements Applicability Evaluation Program for Decommissioning", was issued in June 1994.

Industrial Hyglene (IH) will develop a screening checklist for the site procecures manual outlining work package and job plan review criteria to be submitted to Standards Management by November 30, 1994. Once this procedure has been approved, a letter will be sent to affected divisions and facility management for implementation into work control procedures to direct the work planners, operators and engineers.

A supporting observation associated with this vulnerability was a restricted workday case recorded when an employee received second degree bums after being sprayed with 94 percent sulfuric acid from a broken acid line. An enhancement to the site maintenance programs in response to this incident will be the integration of the Predictive and Preventative Maintenance programs of various site maintenance organizations by March 1995.

Since lead is anticipated to be a major concem in future TD\&D projects, the Site established a Lead Committee to address programmatic issues involving lead. The Site Lead Committee will develop a lead compliance program to coordinate lead removal and management. The program will be consistent with initiatives to address employee exposure, waste, and environmental issues associated with lead. 
Point of Contact: E. J. Kahal / S. R. Salaymeh

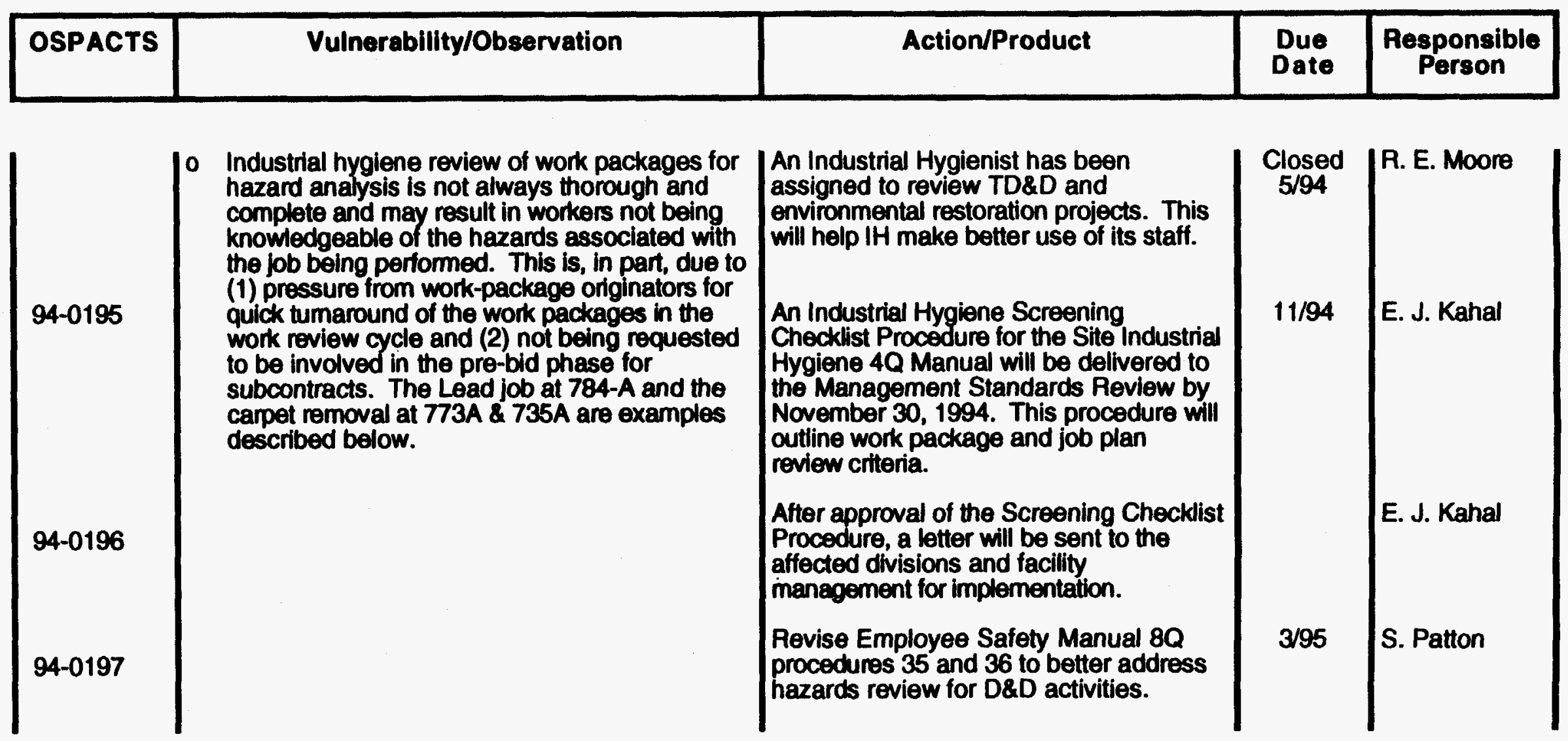




\section{CHEMICAL SAFETY VULNERABILITY REVIEW}

Point of Contact: E. J. Kahal / S. R. Salaymeh

\begin{tabular}{|c|c|c|c|c|}
\hline OSPACTS & Vulnerability/Observation & Action/Product & $\begin{array}{l}\text { Due } \\
\text { Date }\end{array}$ & $\begin{array}{c}\text { Responsible } \\
\text { Person }\end{array}$ \\
\hline $94-0198$ & $\begin{array}{l}\text { - Lead job at 784-A(U). Initially, the contract } \\
\text { specified a torch cutting operation. Instead, } \\
\text { work involved torch cutting of carbon steel } \\
\text { painted with a lead-based paint. This change } \\
\text { in process required the subcontractor to provide } \\
\text { medical surveillance and lead training for } \\
\text { personnel before the work was started. } \\
\text { Consequently, the project was delayed. Had } \\
\text { the work been allowed to start, overexposure } \\
\text { to lead was possible. } \\
\text { 773-A and 735-A Carpet Removal. Initially, the } \\
\text { industrial hygiene representative was informed } \\
\text { that the project was only to remove a carpet. } \\
\text { During removal of that carpet, asbestos- } \\
\text { containing tile was found under the carpet. Due } \\
\text { to the asbestos, this project required several } \\
\text { personnel numerous overtime hours to } \\
\text { complete. } \\
\text { DoE } 5480.23 \text { requires chemical safety analysis } \\
\text { and hazard analysis information to be } \\
\text { developed or updated for nuclear facilities. }\end{array}$ & $\begin{array}{l}\text { The Site Lead Committee will develop a } \\
\text { lead compliance program to coordinate } \\
\text { lead removal and management to be } \\
\text { consistent with initiatives to address } \\
\text { employee exposure, waste, and } \\
\text { environmental issues associated with } \\
\text { lead. } \\
\text { An asbestos management function was } \\
\text { formed in the Engineering \& Projects } \\
\text { Dhision to ensure that SRS cost } \\
\text { effectively complies with existing } \\
\text { asbestos regulations through following a } \\
\text { dedicated central direction and by } \\
\text { controlling sitewide asbestos abatement } \\
\text { functions. }\end{array}$ & $\underset{\text { In }}{\text { progress }}$ & R. Blundy \\
\hline
\end{tabular}




\section{CHEMICAL SAFETY VULNERABILITY REVIEW}

WSRC-RP-94-863

Site/Facility: Savannah River Site

Vulnerability Number: CSVR-SRS-0000-01

Point of Contact: E. J. Kahal / S. R. Salaymeh

\begin{tabular}{|c|c|c|c|c|}
\hline OSPACTS & Vulnerabillty/Observation & Action/Product & $\begin{array}{l}\text { Due } \\
\text { Date }\end{array}$ & $\begin{array}{c}\text { Responsible } \\
\text { Person }\end{array}$ \\
\hline & $\begin{array}{l}\text { Site personnel from the Facility Regulatory } \\
\text { Compliance Group stated that some safety- } \\
\text { related documentation at the Savannah River } \\
\text { Site (SRS) has not been updated for almost } 10 \\
\text { years. Old Salety Analysis Reports (SARs) } \\
\text { may not contain up-to-date chemical safety and } \\
\text { hazard analysis information. } \\
\text { A schedule for SAR updates shows that } \\
\text { update of some SARs may not be completed } \\
\text { for several years. } \\
\text { While the SARs for nuclear facilities are being } \\
\text { updated (long term), the Bases for Interim } \\
\text { Operations (BIOs) should capture the chemical } \\
\text { analysis information sooner. }\end{array}$ & $\begin{array}{l}\text { While some safety-related documentation } \\
\text { may be up to } 10 \text { years old, most SRS } \\
\text { SARs are not. Existing SARs satisfy the } \\
\text { requirements that were active at the time } \\
\text { of their preparation. WSRC continually } \\
\text { strives to improve safety documentation } \\
\text { and has submitted a detailed } \\
\text { implementation plan for DOE Order } \\
5480.23 \text {. } \\
\text { BIOs are being developed on an } \\
\text { accelerated basis and will satisfy the } \\
\text { need for chemical analysis. Some BIOs } \\
\text { have already been approved by DOE } \\
\text { (F-Canyon), while others have been } \\
\text { submitted for approval (SRTC, SWDF). } \\
\text { The last BIO is tentatively scheduled for } \\
\text { submittal to DOE in FY-95. }\end{array}$ & $\ln _{\text {progress }}$ & $\begin{array}{l} \\
\text { S. R. } \\
\text { Salaymeh }\end{array}$ \\
\hline
\end{tabular}


Point of Contact: E. J. Kahal / S. R. Salaymeh

\begin{tabular}{|c|c|c|c|c|}
\hline OSPACTS & Vulnerability/Observation & Action/Product & $\begin{array}{l}\text { Due } \\
\text { Date }\end{array}$ & $\begin{array}{c}\text { Responsible } \\
\text { Person }\end{array}$ \\
\hline & $\begin{array}{l}\text { DOE } 5481.1 \text { B requires chemic } \\
\text { analysis to be developed for nonisulear } \\
\text { facilities. Nonnuclear facility SARs have not } \\
\text { been developed at SRS. Chemical safety } \\
\text { analysis and hazards analysis are not complete } \\
\text { for the nonnuclear facilities. } \\
\text { - Headquarters, DOE, implementation guidance } \\
\text { has not been provided. }\end{array}$ & $\begin{array}{l}\text { The assessment team recognized that } \\
\text { SRS is taking positive actions to } \\
\text { determine which nonnuclear facilities will } \\
\text { be required to have a SAR. WSRC and } \\
\text { DOE-SR are currently determining the } \\
\text { best way to implement DOE Order } \\
5481.1 B \text { in the absence of definitive HQ } \\
\text { guidance. } \\
\text { SRS will be implementing STD-5502-94. } \\
\text { This DOE Standard addresses chemical } \\
\text { hazard analysis. } \\
\text { Chemical hazard analyses are performed } \\
\text { per the "Toxic Chemical Hazards } \\
\text { Classification and Risk Acceptance } \\
\text { Guidelines for Use in DOE Facilities", a } \\
\text { Westinghouse M\&O guidance document. }\end{array}$ & $\begin{array}{c}\text { In } \\
\text { progress } \\
\\
\text { In } \\
\text { progress } \\
\text { In } \\
\text { progress }\end{array}$ & $\begin{array}{l}\text { S. R. } \\
\text { Salaymeh } \\
\\
\text { S. R. } \\
\text { Salaymeh } \\
\text { S. R. } \\
\text { Salaymeh }\end{array}$ \\
\hline
\end{tabular}


Point of Contact: E. J. Kahal / S. R. Salaymeh

\begin{tabular}{|c|c|c|c|c|}
\hline OSPACTS & Vulnerability/Observation & Action/Product & $\begin{array}{l}\text { Due } \\
\text { Date }\end{array}$ & $\begin{array}{c}\text { Responsible } \\
\text { Person }\end{array}$ \\
\hline & $\begin{array}{l}\text { A thorough hazards analysis review for } \\
\text { chemical safety concems related to D\&D } \\
\text { activities is especially important due to the lack } \\
\text { of experience in this area. While most operating } \\
\text { facilities have faily well defined safe operating } \\
\text { envelopes, the same can not be said for D\&D } \\
\text { activities. Many procedures to be used during } \\
\text { D\&D are relatively new to site personnel. } \\
\text { Chemical residuals may also introduce unknown } \\
\text { variables that must be addressed. The } \\
\text { problems that can occur if hazards analysis is } \\
\text { not adequately performed are demonstrated in } \\
\text { the incident that happened at the } 412-D \text { Heavy } \\
\text { Water Extraction facility. On November } 11 \text {, } \\
\text { 1993, a worker appeared to have inhaled toxic } \\
\text { gases after a pipe that contained chemical } \\
\text { residues was cut. Lack of an appropriate } \\
\text { technical assessment and an appropriate } \\
\text { chemical characterization was a contributing } \\
\text { cause in the incident. }\end{array}$ & $\begin{array}{l}\text { A thorough characterization and hazards } \\
\text { analysis will be required before any D\&D } \\
\text { activity by the SRS SWER/TDD } \\
\text { Department that is responsible for D\&D } \\
\text { of facilities. The Basic Requirements } \\
\text { document, "SRS Requirements } \\
\text { Applicability Evaluation Program for } \\
\text { Decommissioning" was issued in June } \\
1994 \text {. } \\
\text { The Type B investigation was } \\
\text { completed January } 25,1994 \text {. }\end{array}$ & $\begin{array}{c}\text { Closed } \\
6 / 94\end{array}$ & $\begin{array}{l}\text { G. Street } \\
\text { B. Myers }\end{array}$ \\
\hline
\end{tabular}


Point of Contact: E. J. Kahal / S. R. Salaymeh

\begin{tabular}{|c|c|c|c|c|}
\hline OSPACTS & Vulnerability/Observation & Action/Product & $\begin{array}{l}\text { Due } \\
\text { Date }\end{array}$ & $\begin{array}{c}\text { Responsible } \\
\text { Person }\end{array}$ \\
\hline & $\begin{array}{l}\text { Neither of the site welding manuals, SRSESM } \\
050507-10 R \text { or CMP 11-10.1, identifies the } \\
\text { need for technical assessment of any potential } \\
\text { intemal chemical contaminants that could be } \\
\text { encountered during a cutting or welding of pipes } \\
\text { or vessels. This requirement has not been } \\
\text { incorporated into these manuals even though } \\
\text { the incident at the } 412-D \text { Heavy Water } \\
\text { Extraction facility occured six months ago. This } \\
\text { indicates that chemical safely is not adequately } \\
\text { covered in some procedures. }\end{array}$ & $\begin{array}{l}\text { SRSESM 050507-10-R (dated 9/30/92) } \\
\text { identifies the need for technical } \\
\text { assessment of potential intermal } \\
\text { contaminants. Several precautions } \\
\text { addressed in this wolding manual make } \\
\text { special mention of fumes and precautions } \\
\text { to address such hazards (ventllation, } \\
\text { exhaust hoods, air flow rates, } \\
\text { respirators). } \\
\text { CMP-11-10.1 was revised and training } \\
\text { began. } \\
\text { wSRC has also consolidated the } \\
\text { welding programs of WSRC and BSRI to } \\
\text { ensure that welding control is uniform. }\end{array}$ & $\begin{array}{c}\text { Closed } \\
6 / 94 \\
\text { Closed } \\
2 / 94\end{array}$ & $\begin{array}{l}\text { D. Harold } \\
\text { D. Harrison }\end{array}$ \\
\hline
\end{tabular}


Point of Contact: E. J. Kahal / S. R. Salaymeh

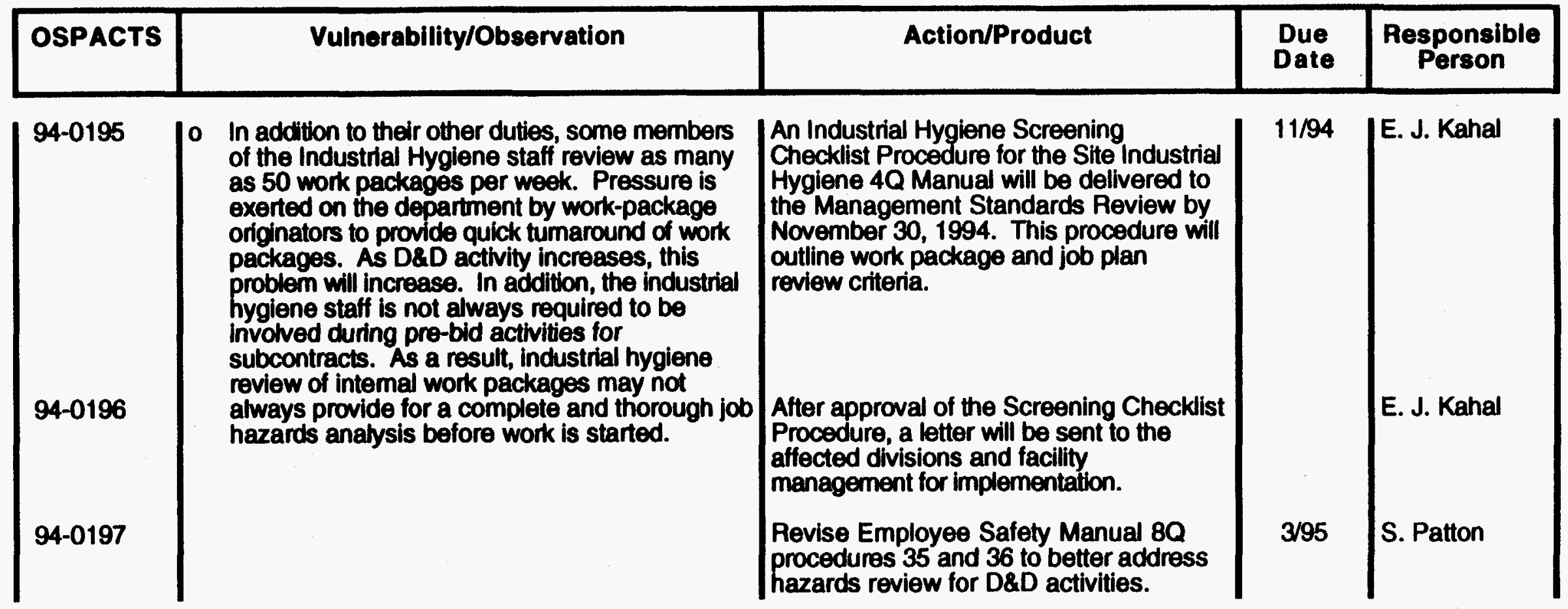


Point of Contact: E. J. Kahal / S. R. Salaymeh

\begin{tabular}{|c|c|c|c|c|}
\hline OSPACTS & Vuinerability/Observation & Action/Product & $\begin{array}{l}\text { Due } \\
\text { Date }\end{array}$ & $\begin{array}{c}\text { Responsible } \\
\text { Person }\end{array}$ \\
\hline & $\begin{array}{l}\text { The Westinghouse Savannah Aiver Company } \\
\text { (WSRC) technical staff believes that the use of } \\
\text { pre-mixed sodium tetraphenylborate solution at } \\
\text { the In-Tank Precipitation Facility, being } \\
\text { dellvered on an as-used basis, will preclude the } \\
\text { possibility of excessive in-tank degradation of } \\
\text { the active reagent and minimize the inventory } \\
\text { (and hence chemical vulnerability) of this } \\
\text { process chemical. The decision to proceed in } \\
\text { this manner has not been finallzed even though } \\
\text { the facillty is being prepared for startup. The } \\
188,000 \text {-gallon tank was designed and } \\
\text { constructed based on limited options related to } \\
\text { existing vendor capability. The requirement for } \\
\text { this large tank has now disappeared, and } \\
\text { recent vendor problems with sodium } \\
\text { tetraphenylborate storage and processing } \\
\text { indicate that smaller onsite quantities of this } \\
\text { solution are advisable. }\end{array}$ & $\begin{array}{l}\text { A task team reviewed potential storage } \\
\text { and delivery options. The team } \\
\text { recommended (and the plant has } \\
\text { accepted) modifying the unloading station } \\
\text { such that the storage tank is by-passed. } \\
\text { The sodium tetraphenyl borate (STPB) } \\
\text { will be untoaded from the tanker straight } \\
\text { to Tank } 48 \text { (thus alleviating the need for } \\
\text { storage of large quantities of STPB in the } \\
\text { facility). }\end{array}$ & Closed & D. Wood \\
\hline $94-0199$ & $\begin{array}{l}\text { A restricted workday case was recorded when } \\
\text { an employee received second degree bums } \\
\text { after being sprayed with } 94 \text { percent sulfuric acid } \\
\text { from a broken ( } 1 \text {-inch diameter) acid line. This } \\
\text { line was not insulated, was unsurveyed for } \\
\text { wall-thickness and deterioration, and was } \\
\text { located such that the failure resulted in a } 20 \text { - to } \\
30 \text {-feet spray distance (which reached an } \\
\text { employee walkway). }\end{array}$ & $\begin{array}{l}\text { SRS will integrate the Predictive and } \\
\text { Preventative Maintenance programs of } \\
\text { various site maintenance organizations } \\
\text { by use of a single set of procedures in } \\
\text { the Maintenance Administrative } \\
\text { Procedure IY Manual. }\end{array}$ & $3 / 95$ & D. Harrison \\
\hline
\end{tabular}


Point of Contact: E. J. Kahal / S. R. Salaymeh

\begin{tabular}{|c|c|c|c|c|}
\hline OSPACTS & Vulnerability/Observation & Action/Product & $\begin{array}{l}\text { Due } \\
\text { Date }\end{array}$ & $\begin{array}{c}\text { Responsible } \\
\text { Person }\end{array}$ \\
\hline & $\begin{array}{l}\text { It was reported by WSAC emergency } \\
\text { management personnel that there was a lack of } \\
\text { concise facility-specific chemical safety analysis } \\
\text { and chemical hazands analysis for facilities at } \\
\text { SRS and this adversely affected the } \\
\text { emergency preparedness program. Information } \\
\text { from chemical safety analysis and hazard } \\
\text { analysis is a basis for developing emergency } \\
\text { preparedness plans and implementing } \\
\text { procedures. These personnel also stated that } \\
\text { hazardous chemical information has not been } \\
\text { kept current in safety related documents. }\end{array}$ & $\begin{array}{l}\text { EMPP-001, "Standards for Development } \\
\text { and Maintenance of Hazards } \\
\text { Assessment", (5/2/94), establishes the } \\
\text { SRS process for developing Emergency } \\
\text { Preparedness (EP) Hazards } \\
\text { Assessments (HA). The HA process } \\
\text { includes the identification and } \\
\text { characterization of hazardous materials } \\
\text { performed in accordance with S-ESA-G- } \\
\text { O001, "Electronic Screening of Chemical } \\
\text { Inventory Information", Rev. } 0 \\
\text { (12/28/93). Chemical inventory } \\
\text { information specific to the EP HA criteria is } \\
\text { made available in each HA that is issued } \\
\text { as a facility engineering technical report. } \\
\text { EP HAs establish the basis for facillty } \\
\text { emergency planning programs. Safety } \\
\text { documentation is being upgraded in } \\
\text { accordance with an Integrated Plan, and it } \\
\text { addresses chemical hazards analysis } \\
\text { within the context of revising each } \\
\text { facility's SAR. SAR Preliminary Hazards } \\
\text { Analysis reports, based on DOE } \\
\text { Standard } 1027 \text { screening criteria, identify } \\
\text { hazardous materials inventories to } \\
\text { establish SAR analytical approaches } \\
\text { and provide an additional source of } \\
\text { chemical inventory information. }\end{array}$ & $\underset{\text { progress }}{\text { In }}$ & J.W. Lightner \\
\hline
\end{tabular}




\section{CHEMICAL SAFETY VULNEAABILITY REVIEW}

Point of Contact: E. J. Kahal / S. R. Salaymeh

\section{Vulnerability}

The knowledge and characterization of chemical residuals at some facilities is not adequate.

\section{Summaxy of Vulnerability}

There is inadequate knowledge and characterization of chemical residuals at some facilities being prepared for D\&D. Poor configuration management in the past and loss of experienced personnel have contributed to this lack of knowledge regarding chemical residuals. A formal program to characterize residuals at surplus facilities being prepared for Decontamination And Decommissioning (D\&D) is not established. Also, hazards analysis performed related to D\&D activities in some cases is inadequate.

\section{Response}

At SRS, the Transition D\&D (TD\&D) Department is responsible for D\&D after facilities are transferred from DP to EM. In transition, surplus facilities are first deactivated, and a safe-storage mode is established with surveillance and maintenance. D\&D will not begin at most facilities for several years after shutdown. Before any D\&D begins, characterization and hazards analysis will be completed. Specific requirements and procedures for the facility involved will be provided before D\&D. These activities are specified in the Basic Requirements document, "SRS Requirements Applicability Evaluation Program for Decommissioning", issued in June 1994. 
Point of Contact: E. J. Kahal / S. R. Salaymeh

\begin{tabular}{|c|c|c|c|c|}
\hline OSPACTS & Vulnerability/Observation & Action/Product & $\begin{array}{l}\text { Due } \\
\text { Date }\end{array}$ & $\begin{array}{c}\text { Responsible } \\
\text { Person }\end{array}$ \\
\hline 94-0200 & $\begin{array}{l}\text { - The knowledge and characterization of chemical } \\
\text { residuals at some facilities is not adequate. } \\
\text { - A formal program to characterize residuals at } \\
\text { surplus facilities being prepared for D\&D is not } \\
\text { established. }\end{array}$ & $\begin{array}{l}\text { Determine method of choice for } \\
\text { atmospheric sampling of unknown gases. } \\
\text { Ensure that all transition and D\&D related } \\
\text { activities conducted by all divisions } \\
\text { follow guidelines of the TD\&D manual } \\
\text { regarding characterization, etc. Most } \\
\text { facilities will proceed from operations to } \\
\text { D\&D via the Transition Process outlined } \\
\text { in the TD\&D Manual. The Basic } \\
\text { Requirements document, "SRS } \\
\text { Requirements Applicability Evaluation } \\
\text { Program for Decommissioning", was } \\
\text { issued in June 1994. }\end{array}$ & $\begin{array}{c}\text { 12/94 } \\
\text { Closed } \\
6 / 94\end{array}$ & $\begin{array}{l}\text { C. Stoyle } \\
\text { G. Street }\end{array}$ \\
\hline
\end{tabular}


CHEMICAL SAFETY VULNERABILITY REVIEW

WSRC-RP-94-863

Site/Facility: Savannah River Site

\section{September 1994}

Vulnerability Number: CSVR-SRS-0000-02

Point of Contact: E. J. Kahal / S. R. Salaymeh

\begin{tabular}{|l|l|}
\hline OSPACTS Vulnerability/Observation \\
\hline
\end{tabular}

- WSRC has established a D\&D policy that defines the actions necessary to transition surplus facilities from an operating status to D\&D. The policy has not been implemented, and detailed requirements are not in place for transfer of shutdown faclities to the Office of Facility Transition and Management (EM-60). Recent direction from Headquarters, DOE, accelerated the schedule for this program to within the next 6 months versus 18 months as originally scheduled. Resource constraints and an accelerated implementation schedule may not permit proper planning and characterization of chemical hazards before facilities are transitioned to EM-60.

- On November 11, 1993, a worker at the 412-D Heavy Water Extraction Facility appeared to have inhaled toxic gases after a pipe that contained uncharacterized chemical residues was cut. Lack of an appropriate technical assessment was a contributing factor in the incident. On November 12, 1993, the Manager of the Savannah River Operations Office directed that a Type B Investigation be conducted in accordance with DOE 5484.1. The Investigation Board recognized that the Savannah River Site (SRS) had insufficient controls in place to prevent the toxic gas inhalation.

Action/Product

\begin{tabular}{c|c|}
\hline Due & $\begin{array}{c}\text { Responsible } \\
\text { Pate }\end{array}$ \\
\hline
\end{tabular}

In this observation. "recommissioning"
should have be should have be: "ather than De
Most facilities win ations to D\&D via the Transition Process outlined in the TD\&D Manual. The Basic Requirements document, "SRS Requirements Applicability Evaluation Program for Decommissioning", was issued in June 1994.

DOE is in the process of making a decision on the date for transfer of facilities at SRS from DP to EM. This could occur as early as January 1995. Characterization can occur after facilities are transferred to EM-60.

An engineer was assigned for technical review of all 412-D work packages and line breaks. Cognizant technical hazard reviewers were also assigned to assess all 412-D acthities.
Closed $6 / 94$

Closed $12 / 93$

B. Myers

\section{G. Street}




\section{CHEMICAL SAFETY VULNERABILITY REVIEW}

Point of Contact: E. J. Kahal / S. R. Salaymeh

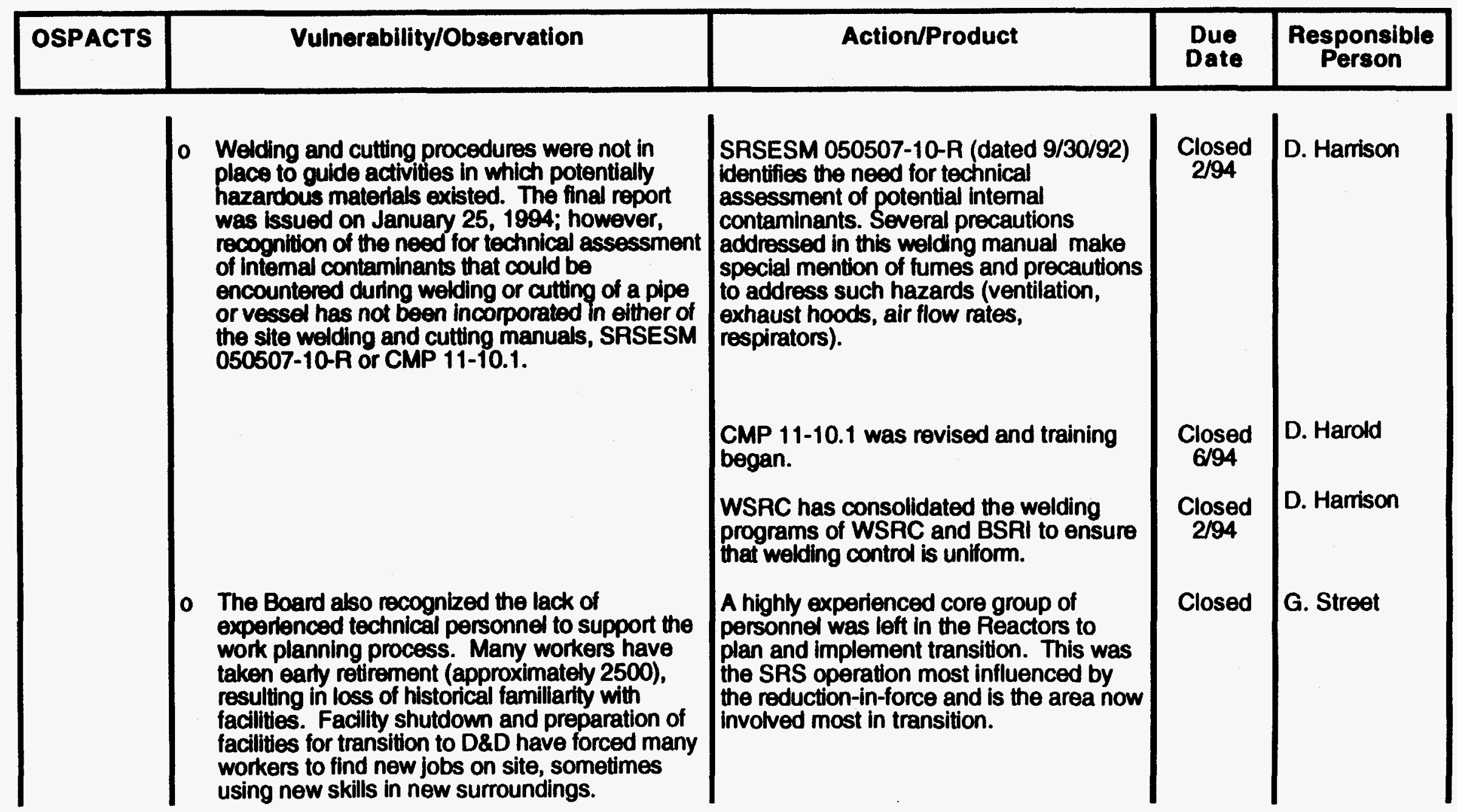


Point of Contact: E. J. Kahal / S. R. Salaymeh

\begin{tabular}{|c|c|c|c|c|}
\hline OSPACTS & Vulnerability/Observation & Action/Product & $\begin{array}{l}\text { Due } \\
\text { Date }\end{array}$ & $\begin{array}{c}\text { Responsible } \\
\text { Person }\end{array}$ \\
\hline & $\begin{array}{l}\text { During a walkthrough of the } 412-\mathrm{D} \text { Heavy } \\
\text { Water Extraction Facility by team members, } \\
\text { chemical residue was observed in a section of } \\
\text { pipe that had been cut by a welding torch. The } \\
\text { residue appears to be very similar to the } \\
\text { residue involved in the incident on November } \\
11,1993 \text {. Pipes continue to be removed using } \\
\text { the original welding and cutting procedures. On } \\
\text { April } 25,1994 \text {, a work package dated March } \\
1994 \text { was reviewed by team members to } \\
\text { determine what employee protective measures } \\
\text { were taken. The package requires fans when } \\
\text { prevaillng wind conditions are not adequate to } \\
\text { remove toxic fumes. At times, asbestos and } \\
\text { acid gas respiratory protection is required (The } \\
\text { employee at the site was wearing respiratory } \\
\text { protection.). The supervisor verified this } \\
\text { procedure was required to ensure protection. } \\
\text { Employees are trained conceming hazards to } \\
\text { be expected during the job. Water is sprayed } \\
\text { on the cut after completion to reduce the } \\
\text { temperature and, thus, stop any exothermic } \\
\text { reaction. }\end{array}$ & $\begin{array}{l}\text { The residue shown to the investigators } \\
\text { was present in various amounts } \\
\text { throughout the entire complex at } 412-D \text {. } \\
\text { Piping has continued to be removed but } \\
\text { not using the original procedures. } \\
\\
\text { An engineer was assigned for technical } \\
\text { review of all } 412-D \text { work packages. } \\
\text { The original package has been revised to } \\
\text { mandate forced air ventilation, if existing } \\
\text { draft ventilation is insufficient. It also } \\
\text { requires the dousing of any torch cut } \\
\text { residue to ensure gases are not } \\
\text { generated, and it requires the use of } \\
\text { barricades. Employees received further } \\
\text { training once the hazands were identified. }\end{array}$ & $\begin{array}{l}\text { Closed } \\
\text { Closed }\end{array}$ & $\begin{array}{l}\text { B. Myers } \\
\text { B. Myers }\end{array}$ \\
\hline
\end{tabular}




\section{CHEMICAL SAFETY VULNERABILITY REVIEW}

Point of Contact: E. J. Kahal / S. R. Salaymeh

\begin{tabular}{|c|c|c|c|c|}
\hline OSPACTS & Vulnerability/Observation & Action/Product & $\begin{array}{l}\text { Due } \\
\text { Date }\end{array}$ & $\begin{array}{c}\text { Responsible } \\
\text { Person }\end{array}$ \\
\hline & $\begin{array}{l}\text { In the self-evaluation submission, WSRC } \\
\text { identified an additional oily substance in the } \\
\text { base of the hot and cold towers with a pH of } \\
\text { approximately } 1 \text {. While sampling and analysis } \\
\text { has been initiated, it has not been vigorously } \\
\text { pursued. On reviewing sampling data at the } \\
400-D \text { Heavy Water Extraction facility, an } \\
\text { analytical report for another olly substance } \\
\text { showed a pH of approximately 3.3. A toxicity } \\
\text { characteristic leachate procedure was not } \\
\text { completed for this substance nor was an } \\
\text { attempt made to identify other residue that could } \\
\text { be present in the towers. }\end{array}$ & $\begin{array}{l}\text { Several samples of the oil/water mixture } \\
\text { were analyzed and the bulk volumes } \\
\text { were collected when they were } \\
\text { encountered as the work progressed } \\
\text { through the columns. } \\
\text { The sample for the oilwater TCLP was } \\
\text { sent to Weston Labs on } 3 / 29 / 94 \text { and } \\
\text { was received back on } 4 / 15 / 94 \text { to the Site } \\
\text { Sample Management Program } \\
\text { organization. The analysis showed a } \\
\text { RCRA hazard due to } 20.5 m g / 1 \text { total } \\
\text { chromium. The TCLP sample of solids } \\
\text { found in the system was sent for } \\
\text { analysis. }\end{array}$ & Closed & B. Myers \\
\hline
\end{tabular}




\section{CHEMICAL SAFETY VULNERABILITY REVIEW}

WSRC-RP-94-863

Site/Facility: Savannah River Site

Vulnerability Number: CSVR-SRS-0000-02

Point of Contact: E. J. Kahal / S. R. Salaymeh

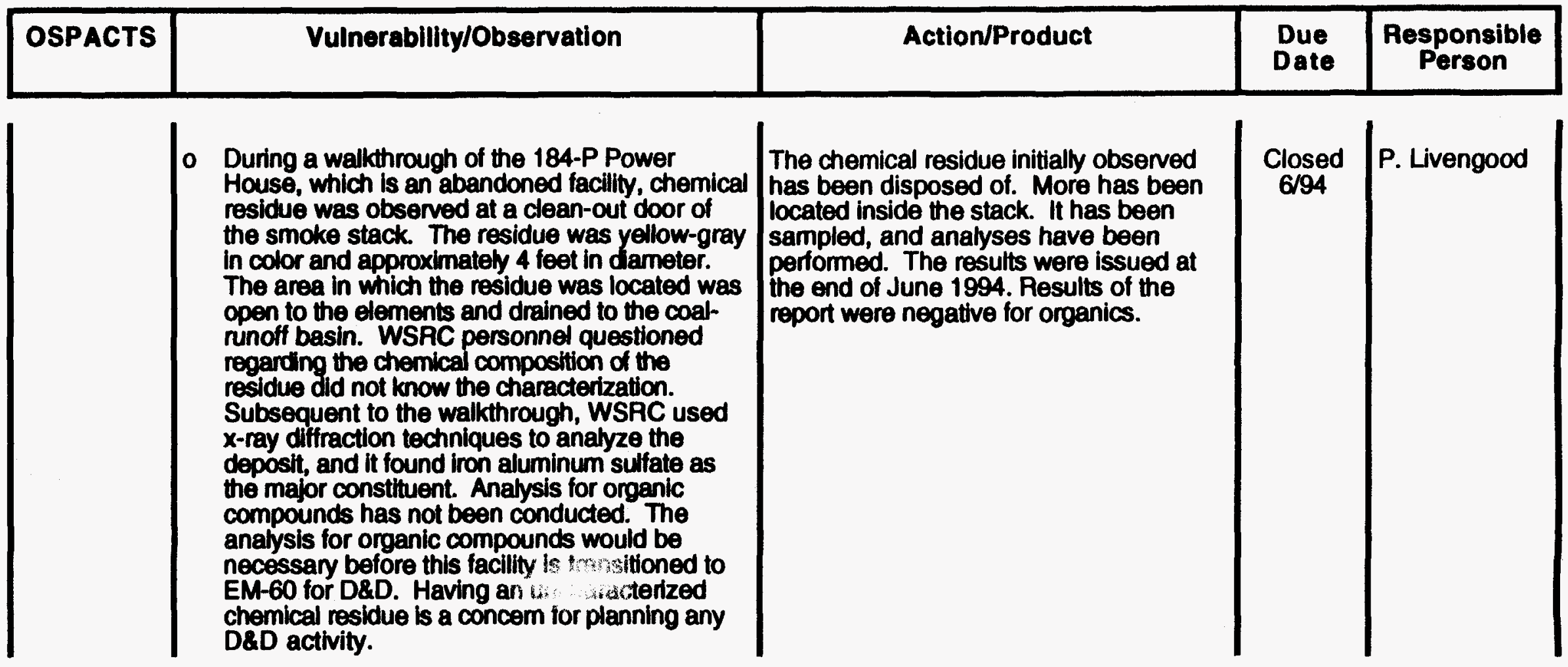




\section{CHEMICAL SAFETY VULNERABILITY REVIEW}

\section{Vulnerability}

In some areas, knowledge about chemicals and chemical inventory and the hazard communication programs are not adequate.

\section{Summan of Vulnerability}

In some cases, important information relevant to chemical safety is not being communicated to workers and management. Situations exist where extremely hazardous chemicals are not tracked, hazards are not adequately communicated, and understanding of chemical safety is incomplete. Expertise is not ahways shared by divisions and facilities to provide the most up-to-date working knowledge of hazards associated with operations activities.

\section{Response}

WSRC has a mechanism for tracking extremely hazardous chemicals; however, the system does not operate in real-time. Site procedures require operating groups to report the presence of any extremely hazardous chemical within 30 days so that it can be reported to the local Emergency Planning Commissions and State authorities (as well as to the Site Fire Department). The issue of realtime reporting will be explored as the new Chemical Commodity Management Center (CCMC) begins to enhance the current Chemical Inventory and Information System.

The WSRC CCMC concept was initiated in May of 1994. An Industrial Hygienist was assigned to this group in July 1994. Its mission will include the acquisition of all chemicals and chemical products, the dispositioning of unused or excess chemicals, and database support for site groups required to report chemical data and weste minimization initiatives to extemal agencies. These changes will help maintain a sitewide chemical inventory and a means of tracking some chemicals from procurement to ultimate use to excessing.

As a part of the writing/reviewing/approving process for the procurement of chemicals, criteria will include such things as evaluating non-hazardous substitutes and re-using current excess and existing inventories. Stores stock items will be reviewed for opportunities to reduce inventory and toxicity levels. 


\begin{tabular}{|l|l|l|l|l|}
\hline OSPACTS & Vulnerability/Observation & Action/Product & $\begin{array}{c}\text { Due } \\
\text { Date }\end{array}$ & $\begin{array}{c}\text { Responsible } \\
\text { Person }\end{array}$ \\
\hline
\end{tabular}

lo There is no system in place at Westinghouse Savannah River Company (WSRC) for managing all aspects of chemicals from procurement to ultimate use and final disposition as elther waste or excess. Furthermore, there is no system for tracking extremely hazardous chemicals once they arrive on site. Although WSRC has recognized this issue and is establishing a Chemical Commodities Management Center, this organization is not expected to be fully functional until the end of 1994. Lack of a system to tras extremely hazardous chemicals represents a vulnerability over the short-term (until the new group is functional).
The WSRC CCMC concept was initiated in May of 1994. Its mission will include the acquisition of all chernicals and chemical products, the dispositioning of unused or excess chemicals, and database support for site groups required to report chemical data and waste minimization initiatives to external agencies. This will include the maintenance of a sitewide chemical inventory and a means of tracking some chemicals from procurement to ultimate use, to excessing.

As a part of the writing/reviewing approving process for the procurement of chemicals, criteria will include such things as evaluating non-hazardous substitutes and re-using current excess and existing inventories. Current stores stock items will be reviewed for opportunities to reduce inventory and toxicity levels.

An Industrial Hygienist was assigned to the CCMC in July 1994.

Benchmark Study of Chemical Tracking/Excess.

\begin{tabular}{c|l} 
Closed & $\begin{array}{l}\text { R. W. } \\
\text { Reynolds }\end{array}$ \\
& \\
Closed & \\
$7 / 94$ & R. E. Moore \\
$11 / 94$ & R. W. \\
Reynolds
\end{tabular}




\section{CHEMICAL SAFETY VULNERABILITY REVIEW}

WSRC-RP-94-863

\begin{tabular}{|c|c|c|c|c|}
\hline OSPACTS & Vulnerability/Observation & Action/Product & $\begin{array}{l}\text { Due } \\
\text { Date }\end{array}$ & $\begin{array}{l}\text { Responsible } \\
\text { Person }\end{array}$ \\
\hline $94-0202$ & & $\begin{array}{l}\text { CCMC will be fully staffed/functional, } \\
\text { which includes review of chemical } \\
\text { requisitions for industrial } \\
\text { hygiene/environmental concems and } \\
\text { consolidation of excess chemical data } \\
\text { from current excess chemical facilities } \\
\text { onsite. }\end{array}$ & $12 / 94$ & $\begin{array}{l}\text { R. W. } \\
\text { Reynolds }\end{array}$ \\
\hline 94-0203 & & Evaluate Stores' Chemical Stock Items. & 3/95 & $\begin{array}{l}\text { R. W. } \\
\text { Reynolds }\end{array}$ \\
\hline $94-0204$ & & $\begin{array}{l}\text { Write/review/approve Site Chemical } \\
\text { Requisitions Centrally. }\end{array}$ & 6/95 & $\begin{array}{l}\text { R. W. } \\
\text { Reynolds }\end{array}$ \\
\hline 94-0205 & & $\begin{array}{l}\text { Initiate Upgrade for Excess Chemical } \\
\text { Warehouse. }\end{array}$ & 6/95 & $\begin{array}{l}\text { R. W. } \\
\text { Reynolds }\end{array}$ \\
\hline $94-0206$ & & $\begin{array}{l}\text { Initiate Excess Chemical Tracking } \\
\text { System. }\end{array}$ & $6 / 95$ & $\begin{array}{l}\text { R. W. } \\
\text { Reynolds }\end{array}$ \\
\hline $94-0207$ & & $\begin{array}{l}\text { Initiate Excess Chemical Sale System } \\
\text { Resulting In High Re-use Rate. }\end{array}$ & 6/95 & $\begin{array}{l}\text { R. W. } \\
\text { Reynolds }\end{array}$ \\
\hline $94-0208$ & & $\begin{array}{l}\text { Enhance current site chemical inventory } \\
\text { system that will improve timeliness and } \\
\text { quality of data. }\end{array}$ & 9/95 & E. J. Kahal \\
\hline
\end{tabular}




\begin{tabular}{|l|l|l|l|l|}
\hline OSPACTS & Vulnerability/Observation & Action/Product & $\begin{array}{c}\text { Due } \\
\text { Date }\end{array}$ & $\begin{array}{c}\text { Responsible } \\
\text { Person }\end{array}$ \\
\hline
\end{tabular}

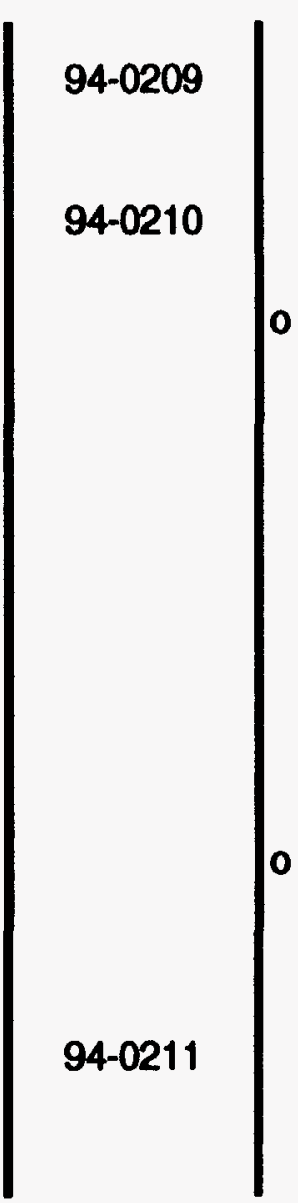

o The present WSRC lessons-leamed program provides thorough information for WSAC management and operating personnel from both intemal and external sources. The program does not specifically separate and highlight chemical safety topics for use by WSRC organizations. This hinders communication of important chemical safety information to workers. WSRC plans to modity the lessons-leamed program within the next six months to identify chemical safety as a specific topic.

- A comprehensive Hazard Uuin. inurication Program that included hazand evaluation, Material Safety Data Sheets (MSDS), hazard waming labels, and information and training has been prepared and implemented at the

Savannah River Site (SRS). Most aspects of the program are in place. However, flaws were observed in this program.

Initiate Site Chemical Tracking System to
include extremely hazardous chemicals.
Finalize Excess Chemical Warehouse
Upgrade.
The implemented corrective action
program:
o identified a list of chemical industry
periodicals that provide a good
coverage of current chemical industry
issues, events, and significant
technical findings, and
have the Site Lessons Learned Staff
screen the material in these sources
for use in the Lessons Leamed
Program.
A committee was formed to investigate
altematives and propose
recommendations to improve the
distribution of MSDS.
Recommendations from the committee are
expected to be complete by October
1994 .

$12 / 95$

$6 / 96$

Closed

5/94
R. W. Reynolds

R. W. Reynolds

G. Ridgely

E. J. Kahal

E. J. Kahal F. 


\begin{tabular}{|c|c|c|c|c|}
\hline OSPACTS & Vulnerability/Observation & Action/Product & $\begin{array}{l}\text { Due } \\
\text { Date }\end{array}$ & $\begin{array}{c}\text { Responsible } \\
\text { Person }\end{array}$ \\
\hline 94-0212 & $\begin{array}{l}\text { Inadequate labeling of containers was } \\
\text { observed in the } 320-M \text { Analytical Laboratory, } \\
\text { Reagent Preparation Laboratory. Several } \\
\text { chemicals did not have the National Fire } \\
\text { Protection Aseociation (NFPA) labels that are } \\
\text { required by the SRS Hazard Communication } \\
\text { Program, and one bottle containing nitric acid } \\
\text { was labeled with the chemical formula only. } \\
\text { The NFPA labelling system does not consider } \\
\text { the target organ in its waming of hazards } \\
\text { associated with a chemical. }\end{array}$ & $\begin{array}{l}\text { Training on labeling was addressed at a } \\
\text { meeting of the site's Chemical } \\
\text { Coordinators. } \\
\text { Submit proposed new chemical label for } \\
\text { management review. }\end{array}$ & $\begin{array}{l}\text { Closed } \\
6 / 94 \\
12 / 94\end{array}$ & E. J. Kahal \\
\hline $94-0213$ & $\begin{array}{l}\text { MSDSs are the major tools for identitying } \\
\text { hazards associated with chemicals and the } \\
\text { actions necessary to mitigate exposures. Many } \\
\text { MSDSs were not readily accessible at SRS. At } \\
\text { the } 734-A \text { Cylinder Shed, MSDSs were stored } \\
\text { in a trailer located more than } 1 \text { block from the } \\
\text { storage area; in the Environmental Laboratory, } \\
\text { room 129, MSDSs were kept in an } \\
\text { administrative office isolated from nomal } \\
\text { laboratory activities; for the L Reactor Chemical } \\
\text { Storage Building, Building } 110-L \text {, MSDSs were } \\
\text { kept in the maintenance shop. }\end{array}$ & $\begin{array}{l}\text { A committee was formed to investigate } \\
\text { altematives and to propose } \\
\text { recommendations for improving the } \\
\text { distribution of MSDS. } \\
\text { Recommendations from the committee are } \\
\text { expected to be complete by October } \\
\text { 1994. }\end{array}$ & $\begin{array}{c}\text { Closed } \\
7 / 94\end{array}$ & E. J. Kahal \\
\hline
\end{tabular}




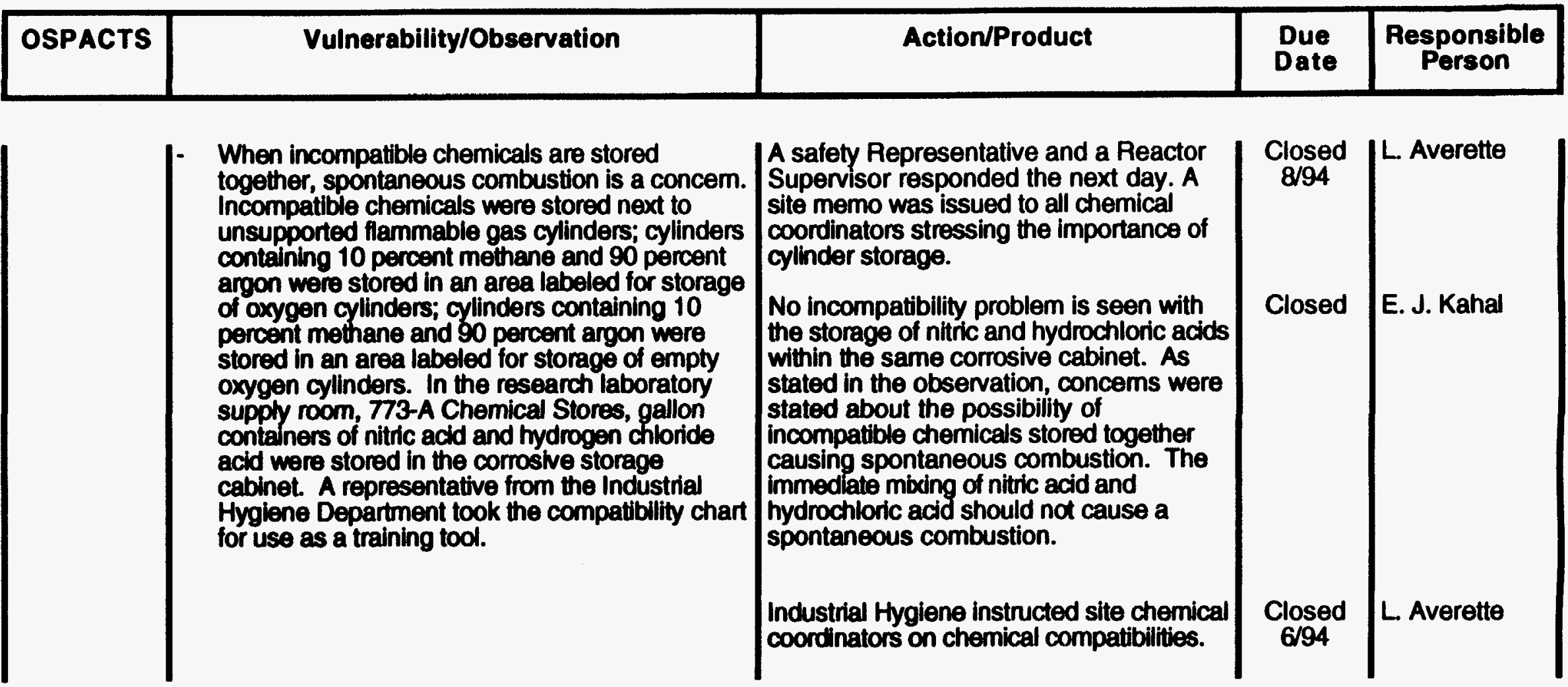




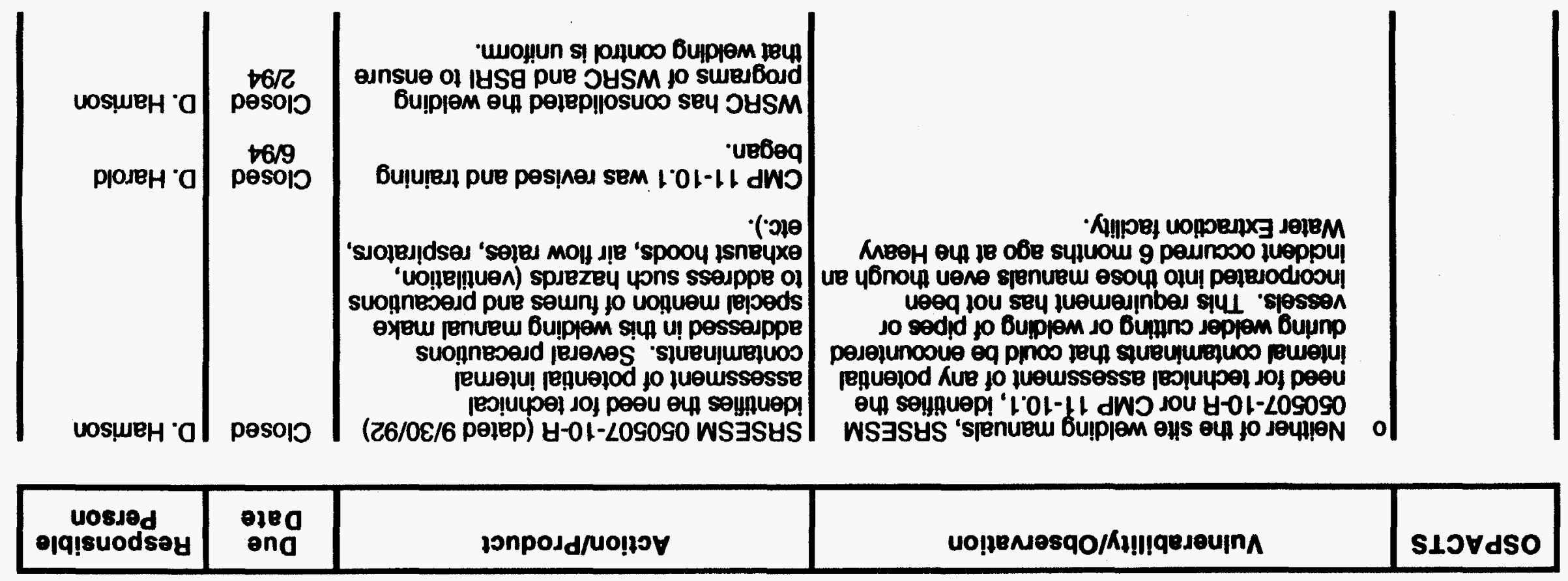

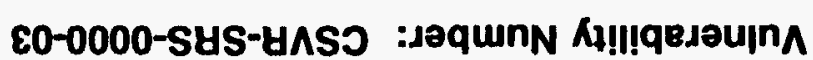




\begin{tabular}{|c|c|c|c|c|}
\hline OSPACTS & Vulnerability/Observation & Action/Product & $\begin{array}{l}\text { Due } \\
\text { Date }\end{array}$ & $\begin{array}{c}\text { Responsible } \\
\text { Person }\end{array}$ \\
\hline $94-0195$ & $\begin{array}{l}\text { Industrial hygiene review of work packages for } \\
\text { hazard analysis is not always thorough and } \\
\text { complete and may result in workers not being } \\
\text { knowledgeable of the hazards associated with } \\
\text { the job being performed. This is, in part, due to } \\
\text { (1) pressure from work-package originators for } \\
\text { quick tumaround of the work packages in the } \\
\text { work review cycle and (2) not being requested } \\
\text { to be involved at the pre-bid phase for } \\
\text { subcontractor. The Lead job at 784-A and the } \\
\text { capet removal at } 773-A \text { \& 735-A are examples } \\
\text { described below.: }\end{array}$ & $\begin{array}{l}\text { An Industrial Hygienist has been } \\
\text { assigned to review TD\&D and } \\
\text { environmental restoration projects. This } \\
\text { will help IH make better use of its staft. } \\
\text { An Industrial Hygiene Screening } \\
\text { Checklist Procedure for the Site Industrial } \\
\text { Hygiene } 4 Q \text { Manual will be delivered to } \\
\text { the Management Standards Review by } \\
\text { November } 30,1994 \text {. This procedure will } \\
\text { outline work package and job plan } \\
\text { review criteria. }\end{array}$ & $\begin{array}{c}\text { Closed } \\
5 / 94\end{array}$ & E. J. Kahal \\
\hline $94-0196$ & & $\begin{array}{l}\text { After approval of the Screening Checklist } \\
\text { Procedure, a letter will be sent to the } \\
\text { affected divisions and ficility } \\
\text { management for implementation. }\end{array}$ & & E. J. Kahal \\
\hline 94-0198 & $\begin{array}{l}\text { Lead Job at 784-A(U). Initially, the contract } \\
\text { spectiled a torch cutting operation. Instead, the } \\
\text { work involved torch cutting of carion steel } \\
\text { painted with a lead-based paint. This change } \\
\text { in process required the subcontractor to provide } \\
\text { medical survellance and lead training for } \\
\text { personnel before the work was started. } \\
\text { Consequently, the project was delayed. Had } \\
\text { this work been allowed to start, overexposure } \\
\text { to lead was possible. }\end{array}$ & $\begin{array}{l}\text { The Site Lead Committee will develop a } \\
\text { lead compliance program to coordinate } \\
\text { lead removal and management to be } \\
\text { consistent with initiatives to address } \\
\text { employee exposure, waste, and } \\
\text { environmental issues associated with } \\
\text { lead. }\end{array}$ & $10 / 94$ & S. Jahn \\
\hline
\end{tabular}




\begin{tabular}{|l|l|l|l|l|}
\hline OSPACTS & Vulnerability/Observation & Action/Product & $\begin{array}{c}\text { Due } \\
\text { Date }\end{array}$ & $\begin{array}{l}\text { Responsible } \\
\text { Person }\end{array}$ \\
\hline
\end{tabular}

773-A and 735-A Carpet Removal. Initially, the industrial hygiene representative was informed that the project was only to remove a rug. During removal of the rug, asbestos containing tile was found under the rug. This process required several personnel to work numerous overtime hours.
An asbestos management function was formed in the Engineering \& Projects Division to ensure that SRS cost

effectively complies with existing asbestos regulations through following a dedicated central direction and by

controlling sitewide asbestos abatement functions.
In progress

R. Blundy 


\section{CHEMICAL SAFETY VULNERABILITY REVIEW}

Point of Contact: E. J. Kahal / S. R. Salaymeh

\section{Vulnerability}

The Westinghouse Savannah River Company (WSRC) lacks a fully developed and implemented chemical safety program.

\section{Summax of Vulnerabillix}

WSRC management systems for chemical safety are not fully implemented, and no overall program is in place for the entire site. This situation arises in part from chemical safety requirements being spread throughout multiple Department of Energy (DOE) Orders. Chemical Center is in the earty stages of development. Until these management systems are developed and implemented uniformly across wi. the effective management and control of hazardous chemicals at the Savannah River Site (SRS) is diminished.

\section{Response}

Chemical safety, as a sitewide program, has not been coordinated as a single unit or under a single group. Figure 1 discussed earlier shows how the Site Safety Review Committee charter will be enhanced to include a person assigned with the responsibility of sitewide coordination of the chemical safety program. The Site Safety Review Committee is made up of senior managers whose mission has been to ensure that programs are covering all aspects of safety and that safety issues are resolved. The Process Safety Management Subcommittee, which addresses the Occupational Safety and Health Administration Process Safety Management requirements rule (and will address the EPA proposed RMP nule as appropriate), and the newly formed Chemical Commodity Management Center, will both serve as key resources for the Site Salety Review Committee. These groups will establish sitewide networks of line organization coordinators to address chemical safety issues. The line organizations will be responsible for implementation of any new initiatives. 


\section{CHEMICAL SAFETY VULNERABILITY REVIEW}

WSRC-RP-94-863

Site/Facility: Savannah River Site

Vulnerability Number: CSVR-SRS-0000-04

Point of Contact: E. J. Kahal / S. R. Salaymeh

\begin{tabular}{|l|l|l|l|l|}
\hline OSPACTS & Vulnerability/Observation & Action/Product & $\begin{array}{c}\text { Due } \\
\text { Date }\end{array}$ & $\begin{array}{c}\text { Responsible } \\
\text { Person }\end{array}$ \\
\hline
\end{tabular}

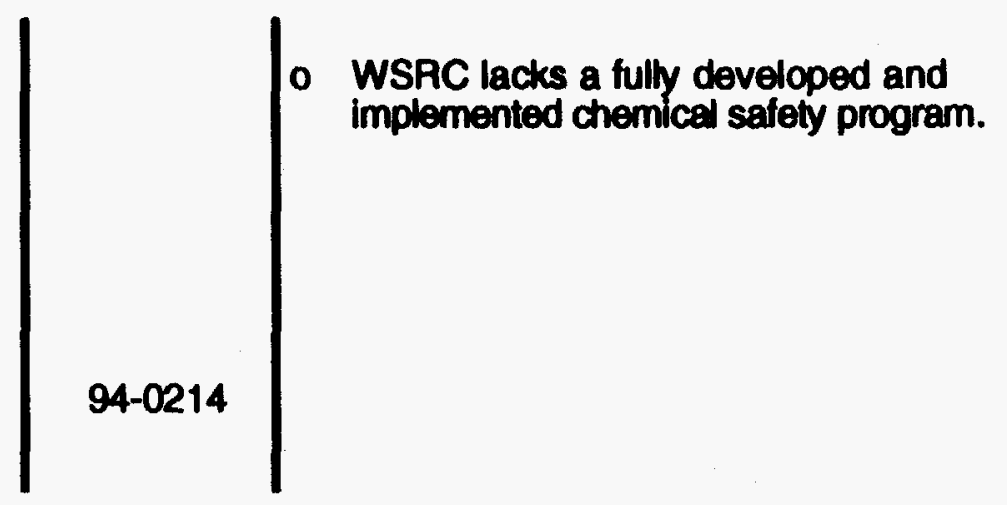

\begin{tabular}{l|l|l} 
The charter of the Site Safety Review & Closed & C. Wolfe \\
Committee (SSRC) has been revised to & \\
include the coordination of a Site & \\
Chemical Safety Program. & \\
Responsibility accepted by SSRC. & $\begin{array}{c}\text { Closed } \\
8 / 94\end{array}$ & C. Wolfe \\
& \\
Assign a cognizant member of the SSRC & $9 / 94$ & C. Wolfe \\
to be responsible for the coordinated & & \\
Chemical Safety Program. & &
\end{tabular}


Point of Contact: E. J. Kahal / S. R. Salaymeh

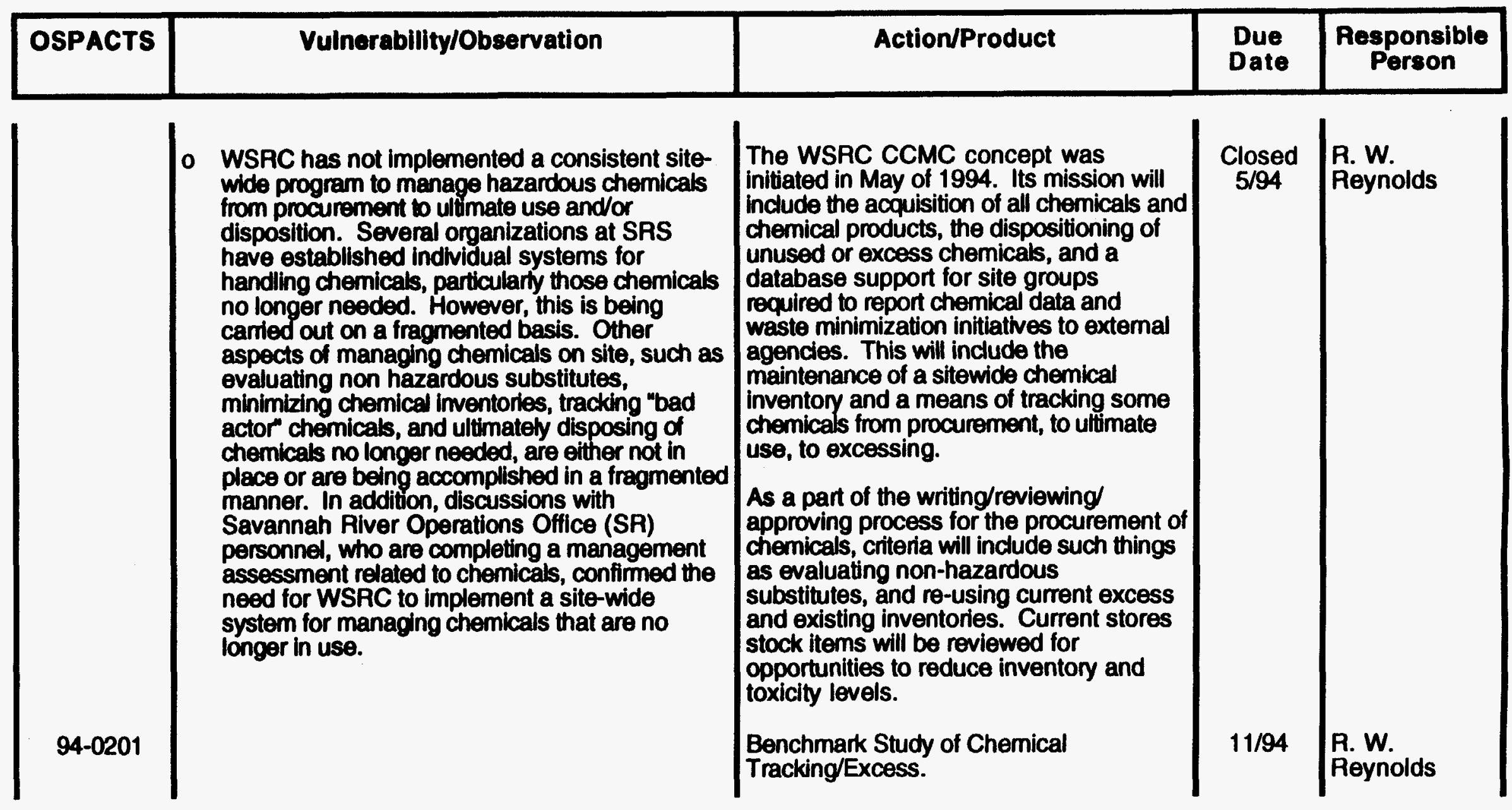


CHEMICAL SAFETY VULNERABILITY REVIEW

WSRC-RP-94-863

Site/Facility: Savannah River Site

Vulnerability Number: CSVR-SRS-0000-04

Point of Contact: E. J. Kahal / S. R. Salaymeh

\begin{tabular}{|c|c|c|c|c|}
\hline OSPACTS & Vulnerability/Observation & Action/Product & $\begin{array}{l}\text { Due } \\
\text { Date }\end{array}$ & $\begin{array}{l}\text { Responsible } \\
\text { Person }\end{array}$ \\
\hline $94-0202$ & & $\begin{array}{l}\text { CCMC will be fully staffed/functional, } \\
\text { which includes review of chemical } \\
\text { requisitions for industrial } \\
\text { hygiene/environmental concerns and } \\
\text { consolidation of excess chemical data } \\
\text { from current excess chemical facilities } \\
\text { onsite. }\end{array}$ & $12 / 94$ & $\begin{array}{l}\text { R. W. } \\
\text { Reynolds }\end{array}$ \\
\hline $94-0203$ & & Evaluate Stores' Chemical Stock Items. & $3 / 95$ & $\begin{array}{l}\text { R. W. } \\
\text { Reynolds }\end{array}$ \\
\hline 94-0204 & & $\begin{array}{l}\text { Write/Review/Approve Site Chemical } \\
\text { Requisitions Centrally. }\end{array}$ & 6/95 & $\begin{array}{l}\text { R. W. } \\
\text { Reynolds }\end{array}$ \\
\hline 94-0205 & & $\begin{array}{l}\text { Initiate Upgrade for Excess Chemical } \\
\text { Warehouse. }\end{array}$ & $6 / 95$ & $\begin{array}{l}\text { R. W. } \\
\text { Reynolds }\end{array}$ \\
\hline $94-0206$ & & $\begin{array}{l}\text { Initiate Excess Chemical Tracking } \\
\text { System. }\end{array}$ & $6 / 95$ & $\begin{array}{l}\text { R. W. } \\
\text { Reynolds }\end{array}$ \\
\hline 94-0207 & & $\begin{array}{l}\text { Initiate Excess Chemical Sale System } \\
\text { Resulting In High Re-use Rate. }\end{array}$ & $6 / 95$ & $\begin{array}{l}\text { R. W. } \\
\text { Reynolds }\end{array}$ \\
\hline $94-0208$ & & $\begin{array}{l}\text { Enhance current site chemical inventory } \\
\text { system that will improve timeliness and } \\
\text { quality of data. }\end{array}$ & 9/95 & E. J. Kahal \\
\hline
\end{tabular}


CHEMICAL SAFETY VULNERABILITY REVIEW

WSRC-RP-94-863

Site/Facility: Savannah River Site

Vulnerability Number: CSVR-SRS-0000-04

Point of Contact: E. J. Kahal / S. R. Salaymeh

\begin{tabular}{|c|c|c|c|c|}
\hline OSPACTS & Vulnerability/Observation & Action/Product & $\begin{array}{l}\text { Due } \\
\text { Date }\end{array}$ & $\begin{array}{c}\text { Responsible } \\
\text { Person }\end{array}$ \\
\hline $94-0210$ & $\begin{array}{l}\text { o WSRC management has recognized the need } \\
\text { for developing programs to deal with most of } \\
\text { the above issues. In response, WSRC is } \\
\text { developing a Chemical Commodity } \\
\text { Management Center that will provide } \\
\text { centralized management of chemicals across } \\
\text { SRS, but that center is not scheduled to be } \\
\text { fully operational until the end of } 1994 \text {. } \\
\text { DOE has not promulgated the requirements for } \\
\text { chemical safety in a single DOE Order. } \\
\text { Instead, the requirements are spread throughout } \\
\text { multple orders that have the effect, in part, of } \\
\text { making different parts of the contractor } \\
\text { organization responsible for their } \\
\text { implementation. This in tum makes chemical } \\
\text { salety program implementation more } \\
\text { susceptible to fragmented implementation, } \\
\text { Particularty at large sites such as SRS. }\end{array}$ & $\begin{array}{l}\text { Initiate Site Chemical Tracking System } \\
\text { To Include Extremely Hazardous } \\
\text { Chemicals. } \\
\text { Finalize Excess Chemical Warehouse } \\
\text { Upgrade. } \\
\text { See response on previous page. } \\
\\
\text { In the absence of DOE-HQ integrated } \\
\text { requirements for chemical safety, WSAC } \\
\text { is integrating the chemical safety } \\
\text { programs and associated activities as } \\
\text { described in this report. }\end{array}$ & $\begin{array}{l}12 / 95 \\
6 / 96\end{array}$ & $\begin{array}{l}\text { R. W. } \\
\text { Reynolds } \\
\text { R. W. } \\
\text { Reynolds } \\
\text { R. W. } \\
\text { Reynolds }\end{array}$ \\
\hline
\end{tabular}




\section{CHEMICAL SAFETY VULNERABILITY REVIEW}

Point of Contact: E. J. Kahal / S. R. Salaymeh

\begin{tabular}{|c|c|c|c|c|}
\hline OSPACTS & Vulnerabillty/Observation & Action/Product & $\begin{array}{l}\text { Due } \\
\text { Date }\end{array}$ & $\begin{array}{c}\text { Responsible } \\
\text { Person }\end{array}$ \\
\hline & $\begin{array}{l}\text { In the P-Reactor Area, personnel have been } \\
\text { assigned to identify excess chemicals in } \\
\text { various locations throughout the area. } \\
\text { Chemicals found are placed in the Reactor } \\
\text { Division Chemical Salvage program. Some of } \\
\text { the chemicals found were not clearty identified or } \\
\text { labeled. This indicates a lack of chemical } \\
\text { inventory control and has a negative effect on } \\
\text { emergency planning for chemical releases from } \\
\text { the area. }\end{array}$ & $\begin{array}{l}\text { An excess chemical facility has been } \\
\text { established in P Area. This facility is not } \\
\text { so much established to identify } \\
\text { chemicals, as all chemicals are } \\
\text { inventoried on the annual SARA Tier II, } \\
\text { but rather to collect and distribute those } \\
\text { chemicals that are no longer used. During } \\
\text { the collection process, some chemicals } \\
\text { did not have labels. These chemicals are } \\
\text { sampled for content and labeled } \\
\text { accordingly. All Reactor Division areas } \\
\text { have been resurveyed and it is } \\
\text { estimated that the program is } 90 \% \\
\text { complete, with expected completion by } \\
\text { the end of the fiscal year. }\end{array}$ & Closed & B. Myers \\
\hline
\end{tabular}


Point of Contact: E. J. Kahal / S. R. Salaymeh

\begin{tabular}{|c|c|c|c|c|}
\hline OSPACTS & Vulnerability/Observation & Action/Product & $\begin{array}{l}\text { Due } \\
\text { Date }\end{array}$ & $\begin{array}{c}\text { Responsible } \\
\text { Person }\end{array}$ \\
\hline & $\begin{array}{l}\text { WSRC plans to implement a Surplus Facilities } \\
\text { Transition Program to formalize requirements for } \\
\text { transitioning surplus facilities from an operating } \\
\text { status to decontamination and decommissioning } \\
\text { (D\&D). When implemented, this program will } \\
\text { require characterization of each facility with } \\
\text { respect to chemical residues. This program is } \\
\text { not currently in place. }\end{array}$ & $\begin{array}{l}\text { At SRS, no facilities have made the } \\
\text { transition to EM-60. In this survey, the } \\
\text { transition process was not understood. } \\
\text { The transition program does not lead to } \\
\text { earty D\&D. Most facilities will proceed } \\
\text { from operations to D\&D via the Transition } \\
\text { Process outlined in the TD\&D Manual. } \\
\text { The Besic Requirements document, } \\
\text { "SRS Requirements Applicability } \\
\text { Evaluation Program for } \\
\text { Decommissioning", was issued June } \\
1994 \text {. } \\
\text { DOE is in the process of making a } \\
\text { decision on the date for transfer of } \\
\text { facilities at SRS from DP to EM. This } \\
\text { could occur as early as January } 1995 \text {. } \\
\text { However, proper planning and } \\
\text { characterization will Occur. } \\
\text { Characterization can occur after facilities } \\
\text { are transferred to EM-60. }\end{array}$ & $\underset{6 / 94}{\text { Closed }}$ & G. Street \\
\hline
\end{tabular}




\section{CHEMICAL SAFETY VULNERABILITY REVIEW}

Point of Contact: E. J. Kahal / S. R. Salaymeh

\begin{tabular}{|c|c|c|c|c|}
\hline OSPACTS & Vulnerabillty/Observation & Action/Product & $\begin{array}{l}\text { Due } \\
\text { Date }\end{array}$ & $\begin{array}{c}\text { Responsible } \\
\text { Person }\end{array}$ \\
\hline & $\begin{array}{l}\text { - A recent SR surveillance report (94-SD-ISB- } \\
\text { O143) on the WSRC Process Safety } \\
\text { Management (PSM) program required by } \\
29 C F A 1910.119 \text { concluded that "WSRC has } \\
\text { not provided site-wide direction or established a } \\
\text { site-wide approach to PSM compliance and } \\
\text { issues." The report noted that each WSRC line } \\
\text { organization approached and interpreted the } \\
\text { standard applicability requirements of PSM } \\
\text { without clear site-wide involvement. }\end{array}$ & $\begin{array}{l}\text { The WSAC Process Safety } \\
\text { Management (PSM) Subcommittee has } \\
\text { been given the task of providing sitewide } \\
\text { direction regarding PSM issues and } \\
\text { establishing a sitewide approach to PSM } \\
\text { compliance. This subcommittee includes } \\
\text { representatives from all site operating } \\
\text { organizations as well as SRTC, E\&PD, } \\
\text { Site Utilities and Analytical Laboratories, } \\
\text { thus ensuring consistent interpretation } \\
\text { and application of PSM requirements. } \\
\text { The PSM Subcommittee will take the } \\
\text { following actions: }\end{array}$ & & $\begin{array}{l}\text { S. R. } \\
\text { Salaymen }\end{array}$ \\
\hline $94-0215$ & & $\begin{array}{l}\text { o Expand charter to include PSM criteria } \\
\text { of } 29 \text { CFR } 1910.119 \text { PSM Rule (and } \\
40 \text { CFR } 68 \text { RMP as required). }\end{array}$ & $11 / 94$ & $\begin{array}{l}\text { S. R. } \\
\text { Salaymeh }\end{array}$ \\
\hline
\end{tabular}


CHEMICAL SAFETY VULNERABILITY REVIEW

WSRC-RP-94-863

Site/Facility: Savannah River Site September 1994

Vulnerability Number: CSVR-SRS-0000-04

Point of Contact: E. J. Kahal / S. R. Salaymeh

\begin{tabular}{|c|c|c|c|c|}
\hline OSPACTS & Vulnerability/Observation & Action/Product & $\begin{array}{l}\text { Due } \\
\text { Date }\end{array}$ & $\begin{array}{l}\text { Responsible } \\
\text { Person }\end{array}$ \\
\hline $94-0216$ & & $\begin{array}{l}\text { Rewrite PHA procedure in } 110 \\
\text { Manual to reflect new PSM criteria } \\
\text { and screening to identify SRS } \\
\text { processes covered by PSM. }\end{array}$ & 2/95 & $\begin{array}{l}\text { S. R. } \\
\text { Salaymeh }\end{array}$ \\
\hline $94-0217$ & & $\begin{array}{l}\text { - Rewrite SRS PSM Manual to } \\
\text { incorporate new PSM criteria and } \\
\text { PHA procedure. }\end{array}$ & $4 / 95$ & $\begin{array}{l}\text { S. R. } \\
\text { Salaymeh }\end{array}$ \\
\hline $94-0218$ & & $\begin{array}{l}\text { - Provide training on new procedure } \\
\text { and expanded PSM program. }\end{array}$ & 6/95 & $\begin{array}{l}\text { S. R. } \\
\text { Salaymeh }\end{array}$ \\
\hline 94-0219 & & $\begin{array}{l}\text { o Monitor consistency of PHAs for input } \\
\text { to SARs and BIOs. }\end{array}$ & $8 / 95$ & $\begin{array}{l}\text { S. R. } \\
\text { Salaymeh }\end{array}$ \\
\hline $94-0219$ & $\begin{array}{l}\text { WSRC does not plan to formally implement a } \\
\text { PSM program untll Fiscal Year 1995 because } \\
\text { there are no hazardous chemicals on site in } \\
\text { quantities that meto oxceed Threshold } \\
\text { Quantity Levels (TQLS). Nevertheless, this } \\
\text { program will be required for compliance with the } \\
\text { currently proposed Environmental Protection } \\
\text { Agency nule for hazardous chemicals or when } \\
\text { quantities of chemicals meet or exceed the } \\
\text { TQLs. }\end{array}$ & $\begin{array}{l}\text { PSM will be implemented as described } \\
\text { above. }\end{array}$ & $8 / 95$ & $\begin{array}{l}\text { S. R. } \\
\text { Salaymeh }\end{array}$ \\
\hline
\end{tabular}




\section{CHEMICAL SAFETY VULNERABILITY REVIEW}

Point of Contact: E. J. Kahal / S. R. Salaymeh

\begin{tabular}{|c|c|c|c|c|}
\hline OSPACTS & Vulnerability/Observation & Action/Product & $\begin{array}{l}\text { Due } \\
\text { Date }\end{array}$ & $\begin{array}{c}\text { Responsible } \\
\text { Person }\end{array}$ \\
\hline & $\begin{array}{l}\text { The present WSRC lessons-leamed program } \\
\text { provides thorough information for WSRC } \\
\text { management and operating personel from both } \\
\text { intemal and extemal sources. However, the } \\
\text { program does not specifically separate and } \\
\text { highlight chemical safety issues and information } \\
\text { for use by the WSRC organizations }\end{array}$ & $\begin{array}{l}\text { The implemented corrective action } \\
\text { program: } \\
\text { o identified a list of chemical industry } \\
\text { periodicals that provide a good } \\
\text { coverage of current chemical industry } \\
\text { issues, events, and significant } \\
\text { technical findings, and } \\
\text { have the Site Lessons Leamed Staff } \\
\text { screen the material in these sources } \\
\text { for use in the Lessons Leamed } \\
\text { Program. }\end{array}$ & $\begin{array}{c}\text { Closed } \\
5 / 94\end{array}$ & G. Ridgely \\
\hline $94-0220$ & $\begin{array}{l}\text { - Completion of training is not consistently } \\
\text { verified before personnel access is granted to } \\
\text { work areas where hazardous chemicals are } \\
\text { located. An exception to this is at the Tritium } \\
\text { and HB-Line areas where access is limited } \\
\text { through issuance of proximity badges to only } \\
\text { those personnel who have completed facility- } \\
\text { speclfic orientation training. No other area of } \\
\text { SRS has this requirement. Under these } \\
\text { conditions, the potential exists that personnel } \\
\text { could be exposed to hazards due to lack of } \\
\text { training and would not know what to do in the } \\
\text { event of an emergency. }\end{array}$ & $\begin{array}{l}\text { Item will be introduced to the Executive } \\
\text { Committee of the Facility Management } \\
\text { Council for consideration. }\end{array}$ & $9 / 94$ & $\begin{array}{l}\text { George Clare, } \\
\text { Chairperson }\end{array}$ \\
\hline
\end{tabular}


Point of Contact: E. J. Kahal / S. R. Salaymeh

\begin{tabular}{|c|c|c|c|c|}
\hline OSPACTS & Vulnerability/Observation & Action/Product & $\begin{array}{l}\text { Due } \\
\text { Date }\end{array}$ & $\begin{array}{c}\text { Responsible } \\
\text { Person }\end{array}$ \\
\hline $94-0221$ & $\begin{array}{l}\text { Training requirements for many contractor and } \\
\text { subcontractor positions at SRS are not } \\
\text { consistently defined or controlled. Training and } \\
\text { qualification program for operators and } \\
\text { supervisors are being upgraded substantially } \\
\text { in some facillies, such as the } H \text { and F Tank } \\
\text { Fams and the Effluent Treatment Facility. In } \\
\text { these facilities, a qualification and requalfication } \\
\text { program is being established, although it is not } \\
\text { scheduled to be fully implemented before } 1996 \text {. } \\
\text { Formal training improvement plans do not exist } \\
\text { for most remaining facilities at the site, and a } \\
\text { goal for site-wide consistency has not been } \\
\text { established. }\end{array}$ & $\begin{array}{l}\text { Site Training Manual } 4 \mathrm{~B} \text { will be rewritten } \\
\text { to cover the training and qualification } \\
\text { program. } \\
\text { Training and qualification requirements for } \\
\text { operators and supervisors at all site } \\
\text { nuclear facilities are identified in DOE } \\
\text { Order } 5480.20 \text {. These requirements are } \\
\text { either met for the operators and } \\
\text { cupervisors in these nuclear facilities or } \\
\text { will be met on schedule* approved by } \\
\text { the Savannah River Operations Office. } \\
\text { Chemical Safety considerations are } \\
\text { addressed in training for personnel in } \\
\text { non-nuclear facilities onsite via GET, } \\
\text { CAT, and, where applicable, OSHA } \\
\text { training. } \\
\text { - WSRC Training Implementation Matrix } \\
\text { WSRC-RP-92-226 }\end{array}$ & $6 / 95$ & Tony Hinson \\
\hline
\end{tabular}




\section{CHEMICAL SAFETY VULNERABILITY REVIEW}

Point of Contact: E. J. KahalS. R. Salaymeh

\section{Vulnerability}

Shifting Departmental priorities is having an adverse effect on the site's overall chemical safety program.

\section{Summan of Vuinerability}

Evolving DOE and SRS missions are resulting in workers being shifted from production work in facilities they are familiar with to cleanup work in less familiar surroundings. Declining budgets are resulting in limited resources to address chemical safety. Continued loss of experienced personnel through early retirement, and possible reductions in environment, safety, and health (ES\&H); quality assurance; and facility maintenance resources may occur in future years at the same time that D\&D activities are increasing.

\section{Response}

Conduct of Operations, a formal, disciplined process for conducting work, is especially important when change is taking place. The correct process for decommissioning a facility must be followed to reduce chemical safety vulnerabilities. Shutdown facilities will be deactivated by experienced personnel who have operated the facility; this includes removing all waste and chemicals from the facility. Vessels and lines will be flushed, and the facility will be characterized and conditions documented. A safe storage condition will be achieved and surveillance and maintenance provided to ensure conditions remain acceptable. After consideration of reuse and analysis of options, D\&D will be planned. In most cases, D\&D of facilities will occur five to ten years after the facility is shutdown. A critical need is that adequate resources be provided to ensure that the proceeding sequence of activities occurs and that the knowledge of current operating personnel is used to achieve these conditions. These activities are specified in the Basic Requirements document, "SRS Requirements Applicability Evaluation Program for Decommissioning", issued in June 1994. 


\begin{tabular}{|l|l|l|l|l|}
\hline OSPACTS & Vulnerability/Observation & Action/Product & $\begin{array}{l}\text { Due } \\
\text { Date }\end{array}$ & $\begin{array}{l}\text { Responsible } \\
\text { Person }\end{array}$ \\
\hline
\end{tabular}

- A critical need is that adequate resources be provided to ensure that the sequence of deactivation, safe storage with survelliance and maintenance and finally, D\&D occurs and that the knowledge of current operating personnel are used to achieve these conditions.

- Many facillties are being shut down and prepared for transition to D\&D. This has forced many workers to find new jobs on site, sometimes using new skills in new surroundings. Additionally, many workers have taken early retirement (approximately 2500) which has resulted in a significant loss of experience. While training programs are in place, the loss of experienced personnel with extensive experience in working with hazardous chemicals can have adverse affects on the overall chemical safety program.
These activities are specified in the basic requirements document, "SRS

Requirements Applicability Evaluation

Program for Decommissioning", which was issued in June 1994.

Facilities are being shut down and deactivated; however, D\&D will not occur inmediately. Although there was a

Reduction-in-Force in 1993, over 17,000 WSRC employees remain. The loss of experienced personnel working with chemicals was not significant.

\begin{tabular}{l|l}
$\underset{6 / 94}{\text { Closed }}$ & G. Street \\
Closed & G. Street
\end{tabular}

Closed

Street 
WSRC-RP-94-863

CHEMICAL SAFETY VULNERABILITY REVIEW September 1994

Site/Facility: Savannah River Site

Vulnerability Number: CSVR-SRS-0000-05

\begin{tabular}{|l|l|l|l|l|}
\hline OSPACTS & Vulnerability/Observation & Action/Product & $\begin{array}{c}\text { Due } \\
\text { Date }\end{array}$ & $\begin{array}{c}\text { Responsible } \\
\text { Person }\end{array}$ \\
\hline
\end{tabular}

- WSRC does not have a formal program to address the loss of experienced personnel due to retirement and declining budgets. However, WSAC (1) regularty recalls retirees to review various areas when questions arise, (2) supports annual gatherings of SAS retirees, and (3) makes use of log books and operating records retained at the site. WSRC plans to continue this approach as SRS moves to increased D\&D activity in the future. However, this leaves the potential for loss of corporate memory. To offset this loss, WSRC management plans to pursue conduct of operations and training when approaching future D\&D projects. Nevertheless, erosion of the experience base is expected to occur as SRS moves to increased D\&D activities.

- Poor configuration management practices in the past have resulted in less than adequate documentation of chemical residuals at some older facilities. In many cases, knowledge related to problems that may be encountered during cleanup resides only in the memories of experienced workers. As older workers are lost through earty retirement (or are replaced by employees not historically familiar with the facility) old problems may surface. This is exacerbated by the length of time between facility shut-down and the time the facility enters D\&D.

While erosion of the experience base is a nomal expectation, the actions described in the observation help minimize any adverse impact to site activities. The few SRS facilities now in D\&D have been shut down from 8 to $\mathbf{3 0}$ years; however, adequate records and/or experienced personnel are available to assist in D\&D planning. For example, retired personnel that operated 232-F are being contracted on a part-time basis to assist in D\&D planning for 232-F. Some personnel who were involved in 412-D operation are still at SRS.

Existing hazard analyses and SARs were prepared in accordance with requirements that were in place at the time of preparation. However, those requirements did not mandate full assessment of chemical hazards. BIOs and DOE 5480.23 SARs now being prepared will establish requirements for "residuals" with respect to ER and D\&D activities. Currently, there is no DOE guidance for addressing residual quantities of hazardous chemicals.
Closed

G. Street

Closed

E. Hallinan 


\begin{tabular}{|l|l|l|l|l|}
\hline OSPACTS & Vulnerability/Observation & Action/Product & $\begin{array}{c}\text { Due } \\
\text { Date }\end{array}$ & $\begin{array}{l}\text { Responsible } \\
\text { Person }\end{array}$ \\
\hline
\end{tabular}

o The availability of industrial hygiene staff to support acthities at SRS is limited. Industrial hyglene support has been noted in past assessments as an area that needs improvement. However, due to continuing constraints on budgets, the situation remains about the same. Despite budget declines, the workload for industrial hygienists has not changed, and extensive overtime is required (the average industrial hygienist works 17 hours of overtime per week). This situation may result in people being less effective, with the possibility of important items being overlooked. WSRC industrial hygiene management is evaluating ways to make more effective use of these personnel, such as allocating them to more critical, higher priority work, and eliminating or changing the way existing lower prionity tasks are performed.

- As part of an intemal budget exercise, WSRC is studying the impact of funding decrements of as much as 30 percent in areas of ES\&H, quality assurance, and maintenance. Such reductions, if implemented, would continue to diminish the overall industrial hygiene program effectiveness. (Hazardous Communication, Health Hazard Assessment, Hazard Prevention and Control, Purchase Approval Program,

Chemical Monitoring, Heat Stress Management, Hearing Conservation).
The Industrial Hygiene \& Respiratory Protection Section is faced with the same budget reductions that are impacting all WSRC organizations. Industrial Hygiene Management continues its aggressive programs of cost effectiveness and focusing resource allocation to high value services. While the initiatives have been successful to date, the ability of the IH\&RP Section to continue achleving higher standards of service necessary to meet the demands of increasing regulatory compliance and changes in new Site missions are ultimately dependent upon maintaining current budget and staffing levels.

These case studies are a part of the budget process.

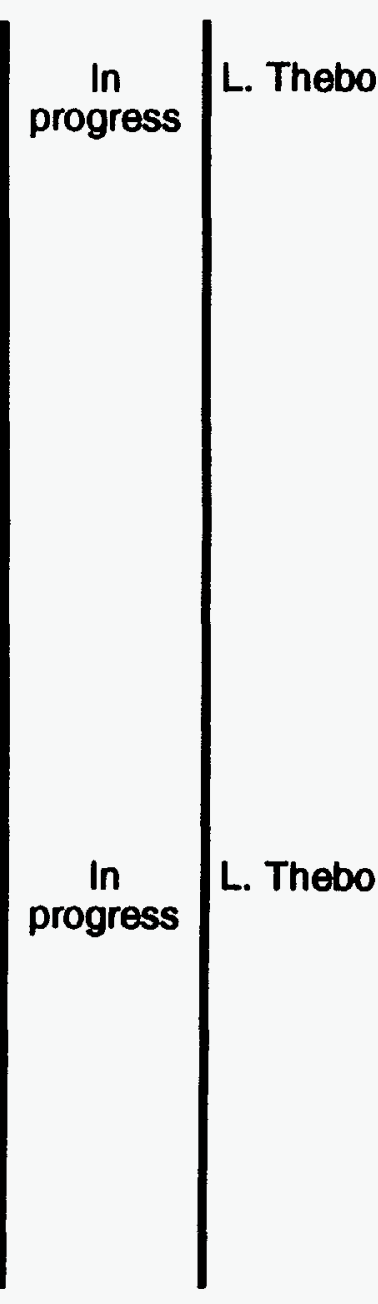


CHEMICAL SAFETY VULNERABILITY REVIEW

WSRC-RP-94-863 September 1994

Site/Facility: Savannah River Site

Vulnerability Number: CSVR-SRS-0000-05

\begin{tabular}{|l|l|l|l|l|}
\hline OSPACTS & Vulnerability/Observation & Action/Product & $\begin{array}{c}\text { Due } \\
\text { Date }\end{array}$ & $\begin{array}{c}\text { Responsible } \\
\text { Person }\end{array}$ \\
\hline
\end{tabular}

- The current five-year WSRC budget plan indicates an essentially constant Full-fime Equivalent (FTE) level for industrial hygiene and safety staff for Fiscal Years 1994 and 1995. However, the plan indicates a decline from 120 FTEs in Fiscal Year 1995 to 114 FTEs in Fiscal Year 1996 and a further decline to 107 FTEs by Fiscal Year 2000. This declining level of resources, crucial to supporting chemical safety, comes at a time when D\&D and waste management activities are increasing at SRS. This apparent disparity, not having sufficient resources available to review the type hazards associated with an increasing and diverse D\&D work environment, represents a potential vulnerability.

- Lack of sufficient resources and a DOEimposed accelerated schedule for implementing the surplus facilities transition program may not permit proper planning and characterization of chemical hazands before D\&D activities start.

A team consisting of representatives of affected programs was assembled to address the identified chemical safety vulnerabilities. The team developed this management response plan.
D\&D activities at SRS will not begin betore proper planning and characterization is completed. Transition schedules may be accelerated, but this only means that ownership of the facilities is transferred from DP to EM. Characterization and deactivation can be completed after transfer. D\&D will probably not begin for several years after deactivation is completed.

\begin{tabular}{|c|c|}
$\substack{\text { Closed } \\
9 / 94}$ & F. Beranek \\
Closed & G. Street
\end{tabular}

